NBER WORKING PAPER SERIES

\title{
THE EFFECT OF TAX RATES AND TAX BASES ON CORPORATE TAX REVENUES: ESTIMATES WITH NEW MEASURES OF THE CORPORATE TAX BASE
}

\author{
Laura Kawano \\ Joel Slemrod \\ Working Paper 18440 \\ http://www.nber.org/papers/w18440
NATIONAL BUREAU OF ECONOMIC RESEARCH
1050 Massachusetts Avenue
Cambridge, MA 02138
October 2012

We are grateful for comments from Kimberly Clausing, Michael Devereux, Martin Feldstein, James Hines Jr., and participants at the NBER 2012 Trans-Atlantic Public Economics Seminar (TAPES) Conference and the 2012 Michigan Tax Invitational Conference. We thank Allison Paciorka, Jacqueline Schwartz and Jonathan Slemrod for their able research assistance and Richard Resen for providing us the 2004 International Bureau of Fiscal Documentation Annual Reports publication. Slemrod acknowledges having had a consulting contract with the International Monetary Fund related to the taxation of multinational corporations over the course of doing the research for this paper. The views expressed herein are those of the authors and do not necessarily reflect the views of the National Bureau of Economic Research and the U.S. Department of Treasury.

NBER working papers are circulated for discussion and comment purposes. They have not been peerreviewed or been subject to the review by the NBER Board of Directors that accompanies official NBER publications.

(C) 2012 by Laura Kawano and Joel Slemrod. All rights reserved. Short sections of text, not to exceed two paragraphs, may be quoted without explicit permission provided that full credit, including $\mathbb{C}$ notice, is given to the source. 
The Effect of Tax Rates and Tax Bases on Corporate Tax Revenues: Estimates with New Measures of the Corporate Tax Base

Laura Kawano and Joel Slemrod

NBER Working Paper No. 18440

October 2012

JEL No. H25

\begin{abstract}
Several recent analyses have suggested that the revenue-maximizing corporate tax rate resides in the low-30's. We challenge this result by re-examining this relationship using a new compilation of changes in corporate tax base definitions for OECD countries between 1980 and 2004. By considering tax base changes in addition to tax rate changes, we can address the estimation bias that applies to tax rates absent their consideration. We find that the relationship between corporate tax rates and corporate tax revenues is tenuous. The large behavioral response to corporate tax rates implied in the literature does not obtain when accounting for persistent differences in tax policy and business environments across countries.
\end{abstract}

Laura Kawano

Department of the Treasury

Laura.Kawano@treasury.gov

Joel Slemrod

University of Michigan Business School

701 Tappan Street

Room R5396

Ann Arbor, MI 48109-1234

and NBER

jslemrod@umich.edu 


\title{
The Effect of Tax Rates and Tax Bases on Corporate Tax Revenues: Estimates with New Measures of the Corporate Tax Base
}

\author{
Laura Kawano and Joel Slemrod*
}

September 28, 2012

\begin{abstract}
Several recent analyses have suggested that the revenue-maximizing corporate tax rate resides in the low-30's. We challenge this result by re-examining this relationship using a new compilation of changes in corporate tax base definitions for OECD countries between 1980 and 2004. By considering tax base changes in addition to tax rate changes, we can address the estimation bias that applies to tax rates absent their consideration. We find that the relationship between corporate tax rates and corporate tax revenues is tenuous. The large behavioral response to corporate tax rates implied in the literature does not obtain when accounting for persistent differences in tax policy and business environments across countries.
\end{abstract}

How responsive a tax base is to the rate of tax applied is a central question in tax analysis. In the past decade, the elasticity of taxable income (ETI) with respect to the marginal tax rate has come to occupy a central role in the normative evaluation of income tax systems 1 Under certain conditions, the ETI summarizes the marginal efficiency cost of raising funds, which in turn plays a central role in the optimal progressivity of the tax system and arguably

\footnotetext{
*Kawano: U.S. Department of Treasury, Office of Tax Analysis, Laura.Kawano@treasury.gov. Slemrod: University of Michigan, Department of Economics, jslemrod@umich.edu. The views expressed in this paper are those of the authors and do not necessarily reflect the policy of the U.S. Department of Treasury. We are grateful for comments from Kimberly Clausing, Michael Devereux, Martin Feldstein, James Hines Jr., and participants at the NBER 2012 Trans-Atlantic Public Economics Seminar (TAPES) Conference and the 2012 Michigan Tax Invitational Conference. We thank Allison Paciorka, Jacqueline Schwartz and Jonathan Slemrod for their able research assistance and Richard Resen for providing us the 2004 International Bureau of Fiscal Documentation Annual Reports publication.

${ }^{1}$ See Feldstein (1995) and Saez (2003) for concise statements of this proposition.
} 
optimal public good provision 2 Although much recent empirical public finance research has focused on quantifying the elasticity of an income tax base to the marginal tax rate applied ${ }^{3}$ with a few exceptions most of it is has addressed the responsiveness of the personal tax base rather than the corporate tax base.

The elasticity of the corporate tax base is of interest to revenue forecasters, but to economists it is largely of interest because of its normative implications, particularly with regard to the appropriate rate of corporate income tax. The basic intuition is that the larger the elasticity, the greater is the efficiency cost per dollar raised of further increases, and the lower is the optimal tax rate. Extending that logic suggests that the rate that maximizes revenue must be higher than the optimal rate, because at that rate a further increase causes distortion but raises no additional revenue.

Some recent papers have estimated the relationship between corporate tax rates and corporate tax revenues, and then used those estimates to calculate an implied revenuemaximizing corporate tax rate in the low-30's. If true, the current U.S. statutory corporate tax rate as of 2012, 35\% plus any state rates, is greater than the revenue-maximizing rate.

This paper challenges the empirical methodology that underlies these results as well as the results themselves by analyzing data for the OECD countries between 1980 and 2004 that includes a new compilation of changes in corporate tax base definitions and enforcement over this period. We first characterize the systematic relationship between statutory rate changes and several categories of base and enforcement (henceforth referred to as base changes) changes. This is relevant for the interpretation of empirical studies on the consequences of rate changes, which generally omit measures of the tax base. Because of this omission, the correlation between rate changes and base changes (together with hypotheses about the independent effect of base changes) is informative about the direction of bias in estimates

\footnotetext{
${ }^{2}$ Slemrod (1998) discusses the conditions under which it is a sufficient statistic for marginal efficiency cost, and Chetty (2009) clarifies those conditions formally.

${ }^{3}$ This literature is critically reviewed in Saez, Slemrod and Giertz (2012).
} 
that are obtained when econometric models exclude such variables. As far as we know, this issue has not heretofore been addressed systematically. But it is well-known that base changes have been prominent in recent tax reforms, at least since the landmark U.S. Tax Reform Act of 1986, which dramatically lowered corporate tax rates but was expected to raise more revenue due to the elimination of the investment tax credit, scaling back of accelerated depreciation allowances, and other base broadeners.

With these data we then estimate the responsiveness of corporate tax revenues with respect to the statutory corporate tax rate and with respect to aspects of the tax base and system of corporate taxation, as well as the interaction between the corporate tax rate and corporate tax base. Because in most cases corporate tax rate schedules are essentially flat rather than graduated, there is a simple relationship between the elasticity of revenues with respect to the tax rate $\left(\varepsilon_{R t}\right)$ and the elasticity of the base with respect to the tax rate $\left(\varepsilon_{B t}\right)$, $\varepsilon_{B t}=\varepsilon_{R t}-1$. We allow the tax base elasticity to vary systematically as a function of non-rate aspects of the tax system. Some of these factors would be expected to affect the breadth of the tax base definition, and so would affect the tax base for any given tax base elasticity. But, as Slemrod and Kopczuk (2002) have suggested and Kopczuk (2005) has demonstrated for the personal tax base, they would also in general affect how responsive are corporate decisions to the statutory tax rate, and thus affect the tax base responsiveness.

We document that corporate tax base changes are more likely to occur in years when there is a change to the corporate tax rate, raising a red flag about the appropriateness of ignoring base changes in a study of the consequences of rate changes. In $51 \%$ of country-years with corporate tax rate changes, there is also a change to the corporate tax base. However, in only $36 \%$ of the country-years where the corporate tax rate is unchanged is there a change to the corporate tax base. We also find limited evidence for a tendency towards tax policies that simultaneously lower the corporate tax rate and broaden the corporate tax base across OECD countries over the period that we consider. When the corporate tax rate decreases, they are 
accompanied by measures that broaden the tax base $39 \%$ of the time, and accompanied by measures that narrow the tax base only $32 \%$ of the time.

In our empirical analysis we find that, using an appropriate econometric specification, the causal relationship between corporate tax rates and corporate tax bases is tenuous. We find that it is important to control for unobserved heterogeneity when estimating the corporate tax base elasticity using cross-country panel data. As initially shown by Gravelle and Hungerford (2007), including country-specific fixed effects in the basic regression framework, which eliminates spurious correlation due to unobserved country-specific variables that affect both tax rates and tax revenues, also eliminates the statistical significance of the relationship between corporate tax rates and corporate tax revenues. When we incorporate our new data on corporate tax base changes, the relationship between the corporate tax rate and corporate tax base remains statistically insignificant. We do find some evidence that the corporate tax appears to play an important role as a backstop for the personal tax base and that corporations shift profits across countries' corporate tax bases.

The effects of some particular aspects of the corporate tax system are notable, and in some cases surprising. As an example of the latter, when there are enhancements to thin capitalization rules, i.e., rules that limit a company's ratio of debt to equity typically meant to regulate the amount of interest that can be claimed as a deduction, corporate tax revenues tend to decrease. Unsurprisingly, there is a positive relationship between increasing the taxation of foreign companies and corporate tax revenues, and between reductions to R\&D credits and corporate tax revenues.

\section{Framework}

Consider a single-period, closed-economy model where the corporate tax schedule has a single rate $(t)$, so that tax revenue $(R)$ is simply proportional to taxable income $(Y)$. Taxable 
income depends in two ways on the non-rate aspects of the tax system (the vector $N$ ) that define the tax base. The first is a mechanical relationship - revenues change when the base changes absent any behavioral response. Second, corporate decisions (the vector $D$ ) may be affected by the non-rate aspects of the tax system via incentive effects; the decisions themselves are generally a function of both $t$ and $N$. As elaborated below, these decisions include real ones such as investment, but also income shifting, avoidance and evasion. Thus we can write:

$$
R=t Y(N, D(t, N))
$$

The value of $N$ may also affect $d D / d t$, and therefore $d Y / d t$, and in turn, the elasticity of taxable income, which is usually defined as $[d Y / d(1-t)][(1-t) / y]$.

A country's statutory rate could affect several categories of decisions, and thereby affect taxable income and revenues. One obvious candidate is taxable income shifting. This shifting could be from high tax-rate countries to low tax-rate countries, reducing tax revenues in the former, but increasing it in the latter. A low rate of corporate tax relative to personal income tax may also encourage businesses to take incorporated form, making them liable to corporate taxes in addition to personal income taxes, and otherwise shift taxable income into the corporate tax base, as examined by Gordon and Slemrod (2002).

A distinct but related avenue of influence that the corporate tax rate has is through its effect on investment. It has been understood at least since Hall and Jorgenson (1967) that the tax disincentive to invest, often referred to as the marginal effective tax rate on investment, depends on not only the statutory rate but on a host of other factors including the schedule of tax depreciation (interacted with inflation), the system of inventory allowances (also interacted with inflation), and the rate of investment tax credit. We denote the marginal effective tax rate on investment as $\tau$, and note that it depends on $t$, some non-rate aspects of the tax system $\left(N_{\tau}\right)$, and some aspects (denoted with a $\tau$ subscript) of the economic environment such as the rate of inflation $(Z)$, so that $\tau=\tau\left(t, N_{\tau}, Z_{\tau}\right)$. Thus (1) can be 
rewritten as $R=t Y\left(N, N_{\tau}, D\left(t, \tau\left(t, N_{\tau}, Z_{\tau}\right)\right)\right.$.

Note that the link between the effect of the tax rate on investment and its effect on revenue is not straightforward. For example, if lower tax rates reduce the effective tax rate on new investment, this may stimulate investment. But, in the short run an increase in investment may reduce, rather than increase, taxable income because at first (accelerated) tax depreciation allowances often exceed any increased profits due to the capital investment and because increased profits may not arise for several years. This is important in part because it suggests that the response lag to tax system changes will vary depending on the kind of behavioral response. For example, the change in taxable income due to income shifting is likely to be relatively fast, but the change in taxable income due to a response in real investment is likely to be slower, and in the short run may be perverse (i.e., more investment may reduce taxable income).

The vectors of the non-rate aspects of the tax system, $N$ and $\left(N_{\tau}\right)$, include elements that are usually characterized as affecting the tax base. One might distinguish two types of baserelated tax system aspects: those that provide behavioral response opportunities, and those that do not. An example of the former is the "domestic production deduction," which allows for a reduction in net income for certain domestic business activities and thus provides an incentive to expand lower-taxed domestic activity at the expense of other activities. Another example is accelerated depreciation. Because depreciation for tax purposes does not equal economic depreciation, the effective tax rate on new investment varies across capital assets and a change in the statutory tax rate will affect the effective tax rate differentially. In contrast, eliminating the deduction for state and local income taxes, while broadening the base, is unlikely to materially affect behavioral response opportunities. Only the former category would be expected to affect the elasticity of response with respect to the statutory rate, by broadening the range of ways in which the tax base could be reduced in response to a higher statutory rate. 


\section{Data}

We focus on the experiences of developed countries over time using data on 29 OECD countries $4^{4}$ For data items aside from our new tax base measures, which we describe shortly, we collect data from 1980 to 2008. We use several sources to compile information on corporate tax systems, corporate tax revenues and other factors that may affect the responsiveness of corporate tax revenues to corporate taxes. Table 1 provides summary statistics for all of these variables, except for the tax base measures.

Data on statutory corporate tax rates is obtained from the University of Michigan World Tax Database for years 1980-2002, supplemented with the OECD Tax Database for years 2003-2008. These data refer to the top marginal income tax rates on domestic corporations at the central government level. Where a surtax applies, we use the statutory corporate rate exclusive of a surtax. Corporate income tax revenues as a fraction of GDP are collected from the OECD Revenue Statistics database. The revenues data refer to central government collections only.

We collect information on several other aspects of taxation systems. Top personal income tax rates at the federal level are collected from the OECD Tax Database for years 1981-2008. We supplement these with personal tax rate data from the World Tax Database for 1980. These are the highest statutory marginal tax rates and, as with corporate tax rates, refer to central government taxes only. The system of dividend taxation and dividend tax rates are obtained from the OECD Tax Database and are available from 1981-2008. To control for the incentive to shift corporate income across countries, for each country in each year we compute the GDP-weighted average of corporate tax rates in the other countries that are

\footnotetext{
${ }^{4}$ The countries are Australia, Austria, Belgium, Canada, the Czech Republic, Denmark, Finland, France, Germany, Greece, Hungary, Ireland, Italy, Japan, South Korea, Luxembourg, the Netherlands, New Zealand, Norway, Poland, Portugal, the Slovak Republic, Spain, Sweden, Switzerland, Turkey, the United Kingdom and the United States. Corporate tax revenue data are not available for Mexico, so Mexico is excluded from our analysis.
} 
included in this study: $:^{5}$

For comparison with previous work, we investigate proxies for the corporate tax base that have been used in previous research. Devereux (2006) uses the present discounted value of depreciation allowances for an investment in plant and machinery; these data are available from the Institute for Fiscal Studies and cover a panel of 16 countries beginning in 1979, all of which are included in this study, and have been updated through $20055^{6}$ Alternatively, Clausing (2007) examines measures of the corporate profit rate and the corporate share of GDP; we construct these measures following her methods using data on corporate value added and operating surplus from the OECD National Accounts Database.

Foreign direct investment data are obtained from the United Nations Conference on Trade and Development Statistics Database, UNCTADstat. The database contains data on inward and outward foreign direct investment stocks and flows.7.$^{7}$ We obtain information on GDP, GDP per capita, GDP growth rates, population growth rates, the proportion of the population residing in urban areas, and unemployment rates from the World Bank's World Development Indicators Database. GDP is reported in current U.S. dollars.8 To account for differences in corporate tax revenue collections due to the size of the financial industry, we use the ratio of central banking assets to GDP from the World Bank database, A New Database on Financial Development and Structure. The methodology for constructing these data are described in Beck, Demirguc-Kunt and Levine (2000).

An important contribution of this paper is the systematic documentation of changes in the breadth and nature of countries' corporate income tax bases. We hand-collect these data from the International Bureau of Fiscal Documentation's (IBFD) Annual Report publications, which provide concise summaries of important tax policy changes in several countries. These

\footnotetext{
${ }^{5}$ The contemporaneous GDP is used for these calculations.

${ }^{6}$ Updated versions of the data used in Devereux and Griffith (2003) are available at http://www.ifs.org.uk/publications/3210.

${ }^{7}$ These data are available at http://unctadstat.unctad.org.

${ }^{8}$ These data are available at http://data.worldbank.org/indicators. We also collect GDP in local currency to compute the corporate profit rate and the corporate share.
} 
publications were produced annually from 1965 through 2002 and then in 2004. For this study, we use publications from 1980 through 2004, so we study 725 potential country-year combinations when corporate tax base measures are included in the analysis..$^{9}$

From the descriptions of tax policy changes, we code changes to several aspects of the corporate tax base. We assign noted changes in the tax base into one of the following twelve categories:

1. the research and development tax credit

2. credits for foreign taxes paid

3. the tax treatment of foreign companies, such as credits or other incentives to attract foreign investment

4. policies that target evasion or avoidance by companies

5. investments credits or other tax incentives to promote investment

6. accelerated depreciation or other depreciation allowances

7. other tax rates that may affect the corporate tax base, e.g., net worth tax on corporations or extraordinary profits tax

8. loss carry-forward rules

9. loss carry-back rules

10. thin capitalization rules

11. controlled foreign company ( $\mathrm{CFC})$ legislation

12. other changes to the corporate tax base

A detailed explanation of the ways that we have translated the IBFD descriptions of tax policy changes into our twelve indicator variables is provided in the Data Appendix.

For all of our tax base measures, we code a change that broadens the tax base system (defined as increasing tax revenue for a given tax rate, other tax base aspects, and behavior)

\footnotetext{
${ }^{9}$ The 2004 publication also contains information on tax policy changes that were enacted in 2003.
} 
as +1 and we denote a change that shrinks the tax base as -1.10 For the tax credits, depreciation allowances, loss carry back and loss carry forwards, a coding of -1 is equivalent to the provision becoming more generous to the taxpayer, whereas +1 refers to the provision becoming less generous. Foreign companies taxed equals +1 when taxes on foreign firms became more extensive. Changes in thin capitalization rules are coded to be equals +1 when thin capitalization legislation was introduced or strengthened. CFC legislation equals +1 when such legislation was introduced. Evasion equals +1 whenever there was mention of initiatives to addresses tax evasion or avoidance, except when it was indicated that these measures were directed solely to the non-corporate sector. Increases in a non-corporate tax rate are recorded as +1 , while decreases are recorded as -1.11

Counts for these measures of tax base changes are provided in Table 2, Overall, we observe that changes to the corporate tax base noted in the IBFD's Annual Reports are a fairly frequent phenomenon. There are 433 changes to the corporate tax base. The majority of these changes broadened the tax base, but there are substantial occurrences of narrowing the base. We label 248 of the tax base changes as making the base broader, and 185 as making the base less broad. Because there may be more than one base change for a given country in a given year, there was at least one base change in just 289 (out of 725) country-years. Thus, in $41 \%$ of country-years, there was at least one base change.

Tabulations of country-years for which we observe multiple changes to the corporate tax base by base-broadening and base-narrowing measures are provided in Table $44^{12}$ The majority of tax policy changes that we document contain only tax base broadening or tax

\footnotetext{
${ }^{10}$ There are a few cases where there are several changes to the same tax base measure. For example, there may two policies that are aimed at reducing tax avoidance behaviors in the same year. In these instances, we do not adjust our measurements beyond the +1 and -1 schematic.

${ }^{11}$ Taxes that are included in the other-rate-change category are: (exceptional, extraordinary, excess) profits or income taxes, movable capital taxes, business capital or immovable property taxes, property transfer taxes, special corporation taxes, industry-specific taxes (manufacturing, petroleum, shipping, oil companies, banking, financial institutions, life insurance companies), taxes on large corporations only, and the corporate AMT.

${ }^{12}$ Note that the maximum number of base-broadening or base-narrowing measures that we observe occurs within a country in a single year is 4 .
} 
base narrowing measures ( $84 \%$, i.e., of the 289 country-years where there was any tax base change, 243 contained only tax base changes in one direction). In these cases, there is an unambiguous change in the breadth of the tax base. However, there are some instances where polices have adjusted the definition or enforcement of the corporate tax base, and we are unable to determine the net impact of these policies to the corporate tax base with our binary measures alone.

Table 5 provides tabulations of tax rate changes and tax base changes by country. We observe that all countries in our sample have changed their top statutory corporate tax rate in our sample period. Moreover, with the exceptions of Iceland and Switzerland, we document some change to the corporate tax base for all countries in our sample. Thus, we see variation in both corporate tax rates and tax bases across most countries, rather than these changes being concentrated in only a few countries. We return to discuss in detail the pattern of base changes and their relationship to rate changes in Section IV.

\section{Corporate Tax Rates and Revenue}

\subsection{Aggregate Time Series}

Some simple correlations suggest that the elasticity of the corporate tax base with respect to the statutory rate may be substantial. First, consider the aggregate time trend. On average, statutory corporate tax rates in OECD countries have fallen significantly since the early 1980s, while over the same period until 2008 revenues from corporate taxes have been buoyant. Figure 1 shows that, after holding constant during the early 1980s, the average statutory corporate tax rate began to fall noticeably.13 The left panel of Figure 1 depicts the unweighted average top statutory corporate tax rate over time, while the right panel

\footnotetext{
${ }^{13}$ These rates refer to federal or central government tax rates only.
} 
depicts this average weighted by GDP ${ }^{14}$ The dashed lines indicate a one standard-deviation interval around the average rates. Weighting the statutory tax rates does not qualitatively affect these patterns.
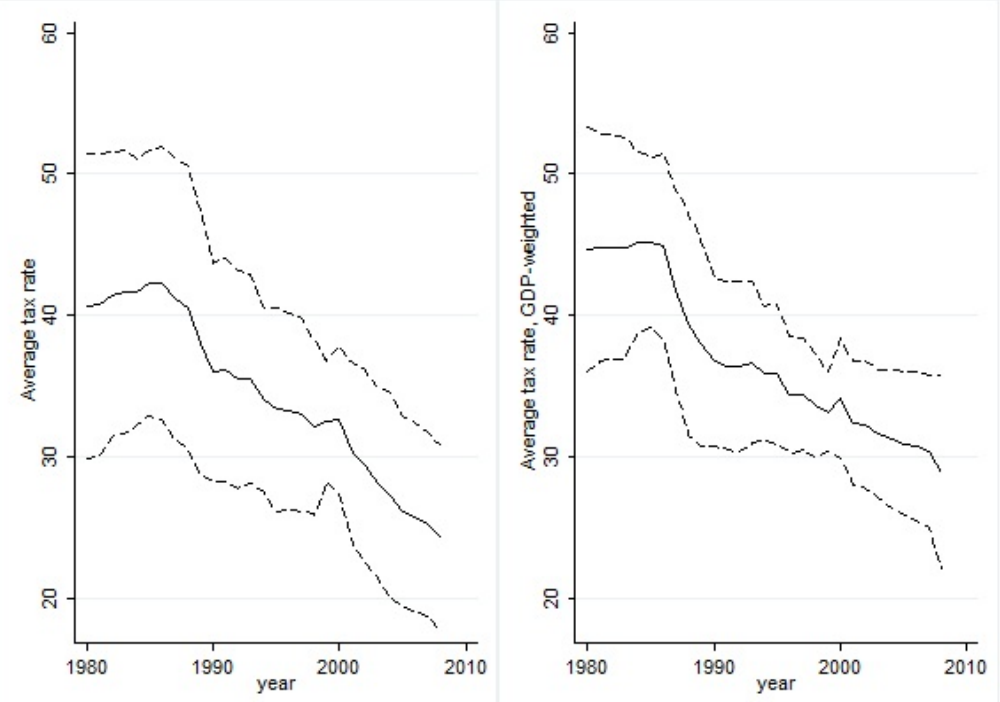

Figure 1: Average OECD corporate tax rates, 1980-2008

To demonstrate that this dramatic change in the average corporate tax rate is not due solely to very large drops in just a few countries, but reflects a decline in most of the countries, Figure 2 shows changes in corporate tax rate for 30 OECD countries. Changes in rates between 1980 and 1994, chosen because it is halfway between 1980 and 2008, are shown in black, while changes between 1994 and 2008 are shown in gray. The change from the beginning to the end of our sample can be obtained by adding the bars together. The figure shows that most countries decreased their corporate tax rates over the sample, as most of the bars fall below zero. In addition, the tax rate increases that exist are much smaller in magnitude than the tax rate decreases. Comparing tax rates in 1980 and in 2008, 21 out of the 24 countries with available data reduced their tax rate and only three increased it. In many cases, the fall has been substantial. In 1980, 14 of the 24 countries had statutory

\footnotetext{
${ }^{14}$ GDP corresponds to the same year as the corporate tax rate, reported in 2010 U.S. dollars. These data are from the World Bank's Web Database, as described in Section 2 .
} 
corporate tax rates of $40 \%$ or more; by 2002 and through 2008 , there were none.

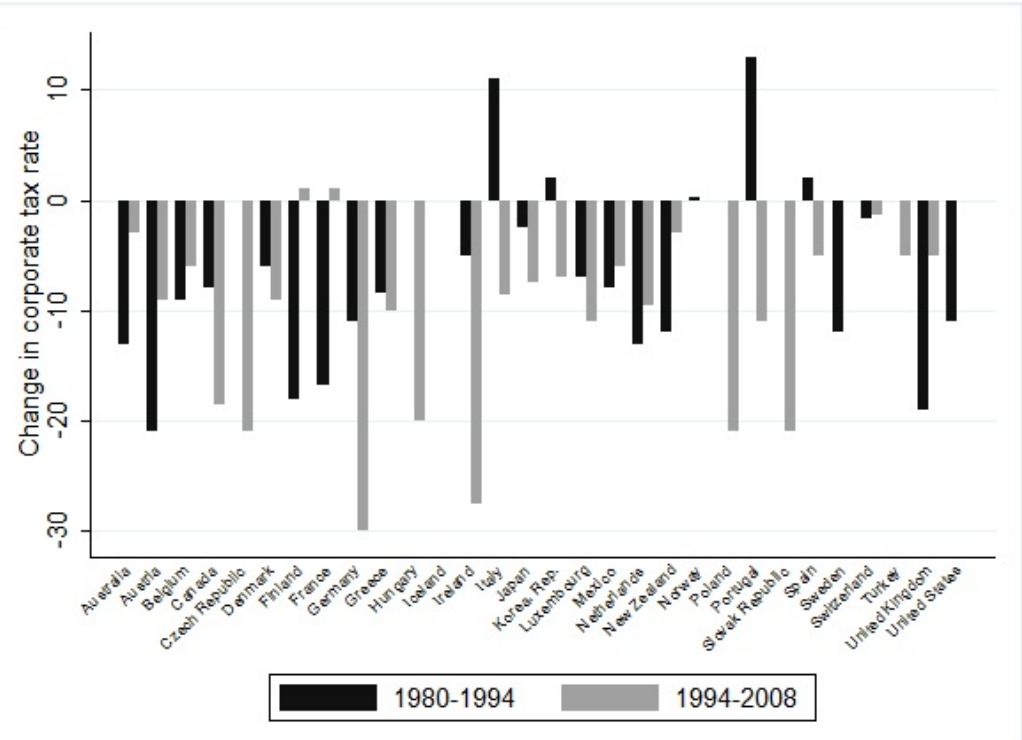

Figure 2: Changes in corporate tax rates by country: 1980-1994 and 1994-2008

The time-series of corporate tax revenues looks quite different, and in particular exhibits no secular decline. Due to differences in country size, we scale tax revenues in each country by GDP to compare total corporate income tax revenues across countries ${ }^{15}$ The right panel of Figure 3 presents the GDP-weighted average value of the ratio of corporate tax revenues to GDP across the same group of countries and the same time period, along with its one-

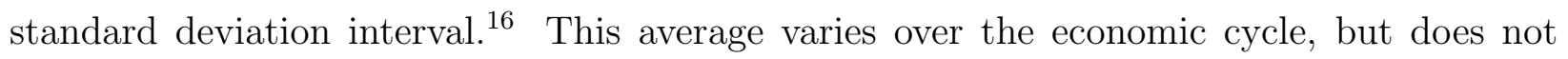
appear to follow any long-term trend. In all years it is within the interval from $2.4 \%$ to $3.6 \%$ of GDP, beginning in 1980 at $2.9 \%$ and ending in 2008 at 3.0\%. In contrast, the left panel of Figure 3 presents the unweighted average value of the ratio of corporate tax revenues to GDP. In 1980 this stood at 2.3\% - that is, on average, corporate tax revenues amounted to $2.3 \%$ of GDP. This average rose slightly in the first half of the 1980 s to reach $2.6 \%$ by

\footnotetext{
${ }^{15}$ Two standard ways of comparing corporate tax revenues across countries are to scale tax revenues in each country by GDP - as done in Figure 3 - or by total tax revenues. These measures will vary for reasons other than the corporate tax system. For example, both depend on the size of the corporate sector (e.g., the degree to which business is incorporated) and on the relative size of corporate income in GDP, which varies considerably over the economic cycle.

${ }^{16}$ Contemporaneous-GDP-weighted averages are equivalent to aggregate tax revenues.
} 
1985, where it remained fairly constant until the 1990s. After that, however, it has rapidly increased. It peaked at $3.6 \%$ in 2000 , and then again at $3.9 \%$ in 2007.17
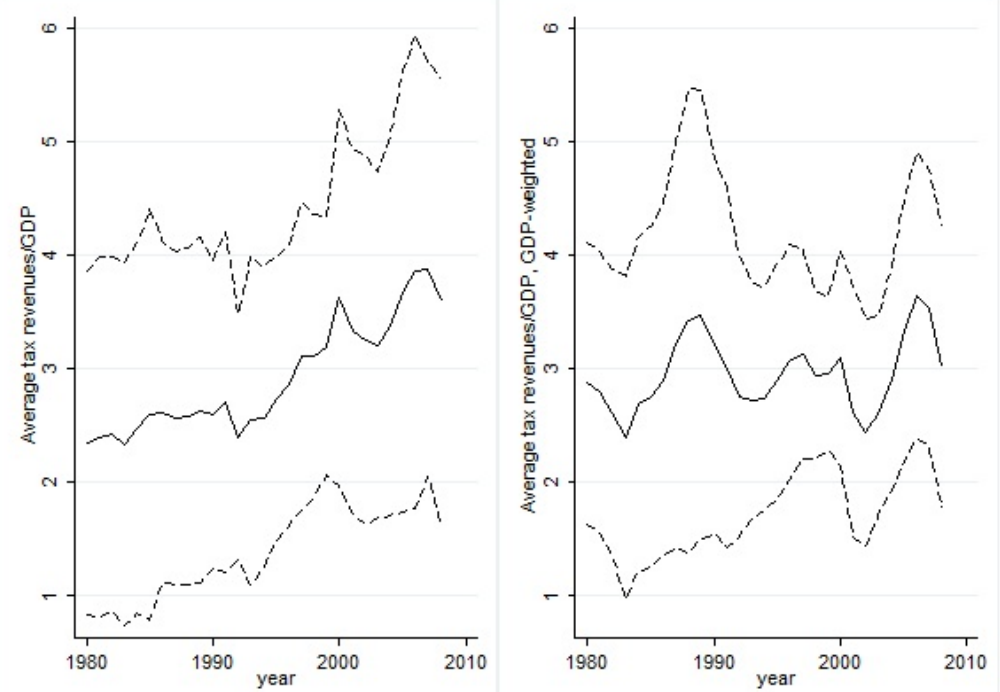

Figure 3: Corporate tax revenues divided by GDP, 1980-2008

The comparison between the weighted and unweighted averages clearly indicates that, relatively speaking, small countries have been increasingly reliant on corporate tax revenues. Figure 4 shows changes in corporate income tax revenue as a proportion of GDP from 1980 to 1994 and from 1994 to 2008. The variation across countries is considerable: some of the smaller countries raised less than $2 \%$ of GDP from corporate income taxes in 1980; by contrast, Luxembourg raised over 6\% in 1994. Between 1980 and 2008 most countries experienced an increase in tax revenues as a proportion of GDP. There are five exceptions, ${ }^{18}$ but only Japan experienced a drop in excess of 1 percentage point. Between 1994 and 2008, in six countries the ratio declined, in none of them by more than 1 percentage point. Norway is an outlier in this series, with a large increase in corporate tax revenues driven largely by

\footnotetext{
${ }^{17}$ The 2008 corporate tax revenue-to-GDP data were not available for five countries: Australia, Greece, Mexico, the Netherlands, and Poland. In previous years, these countries had a higher average revenue-toGDP ratio than those with data available for 2008. These missing data points may account for the dip in the revenue-to-GDP series in 2008.

${ }^{18}$ These are Canada, Germany, Japan, Luxembourg, and the United States.
} 
the oil and gas industry.

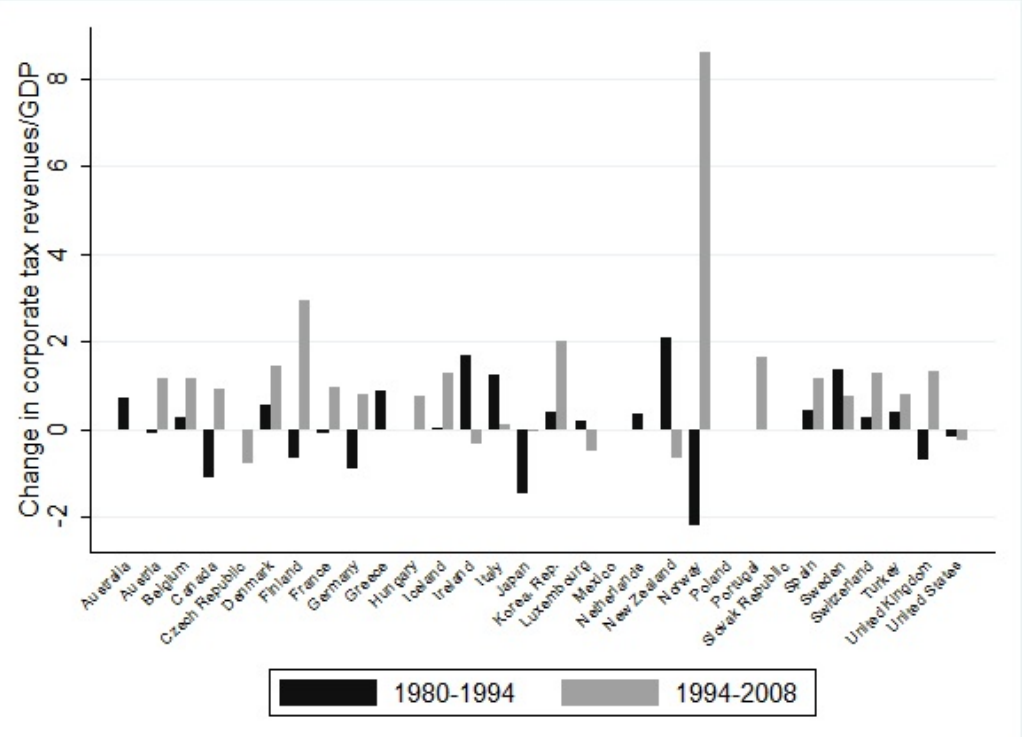

Figure 4: Corporate tax revenues to GDP: 1980, 1994, and 2008

In summary, corporate tax rates have fallen substantially across OECD countries over the past four decades. This decrease is observed in nearly all OECD countries and is not driven by very large decreases by a small number of countries. At the same time, the overall ratio of corporate tax revenues to GDP has remained relatively stable and may have slightly increased, and some countries have substantially increased their reliance on corporate taxes for revenue. This is consistent with a substantial negative correlation between the tax base and the tax rate, whether due to behavioral responses or concurrent statutory base changes.

\subsection{Cross-country}

Looking across countries at a point in time reveals little sign of a strong positive relationship between the statutory corporate tax rate and corporate tax revenues. Figure 5 plots these two variables against each other for 1980 and 2008. As we saw previously, Norway is an outlier with very high tax revenue and a moderate tax rate, reflecting that its corporate tax base and revenues tend to be high because of North Sea oil and gas. 

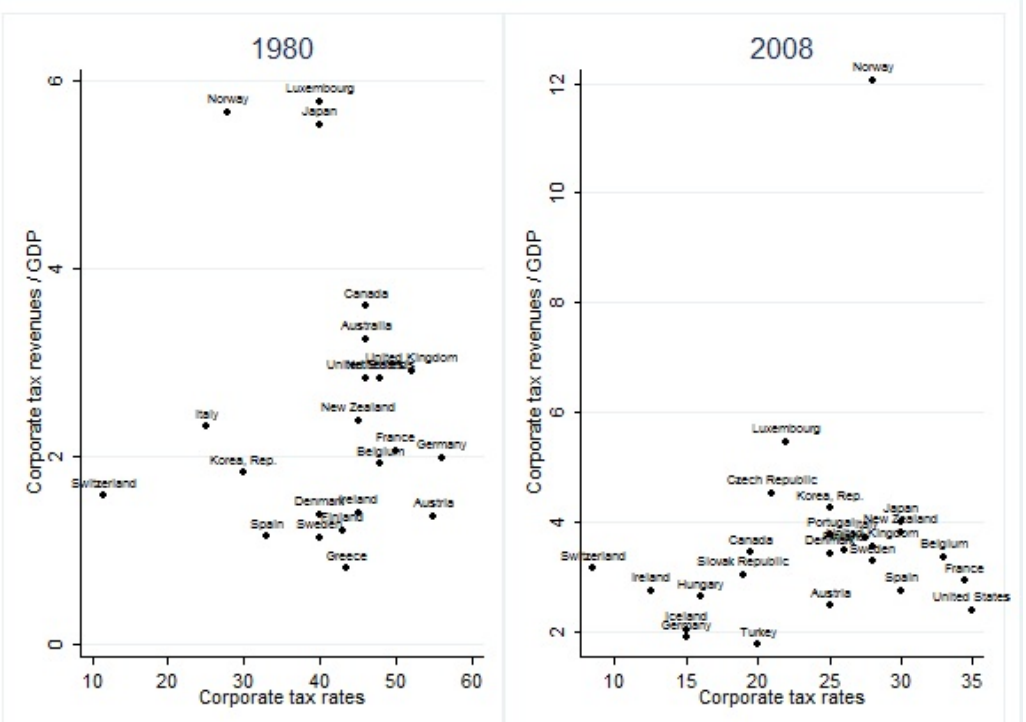

Figure 5: Corporate tax rates and revenues, 1980 and 2008

To depict the relationship between changes in corporate tax rates and changes in corporate tax revenues, Figure 6 plots these patterns. For each country, we compute the change in corporate tax rates and the change in the corporate tax revenue to GDP ratio between the last year in which both variables are available and the first year in which both variables are available. In the figure, a positive relationship is observed.

Complementary evidence on the relationship between changes in the breadth of the corporate tax base and changes in corporate tax revenues is presented in Figure 7. To summarize the change in a country's corporate tax base over time, we sum over the tax base indicators within a country over all years that they are in the sample. In this way, a measure that shrinks the corporate tax base, which we code as -1 , will negate the impact of a measure that broadens the corporate tax base, coded as +1 . Overall, the more positive this measure is, the more frequent were changes to broaden the corporate tax base. A negative value of this measure indicates that there were more measures that shrank the corporate tax base than measures that broadened it. The change in corporate tax revenues is as defined above, except we restrict observations on corporate tax revenues to between 1980 and 2004 because those 


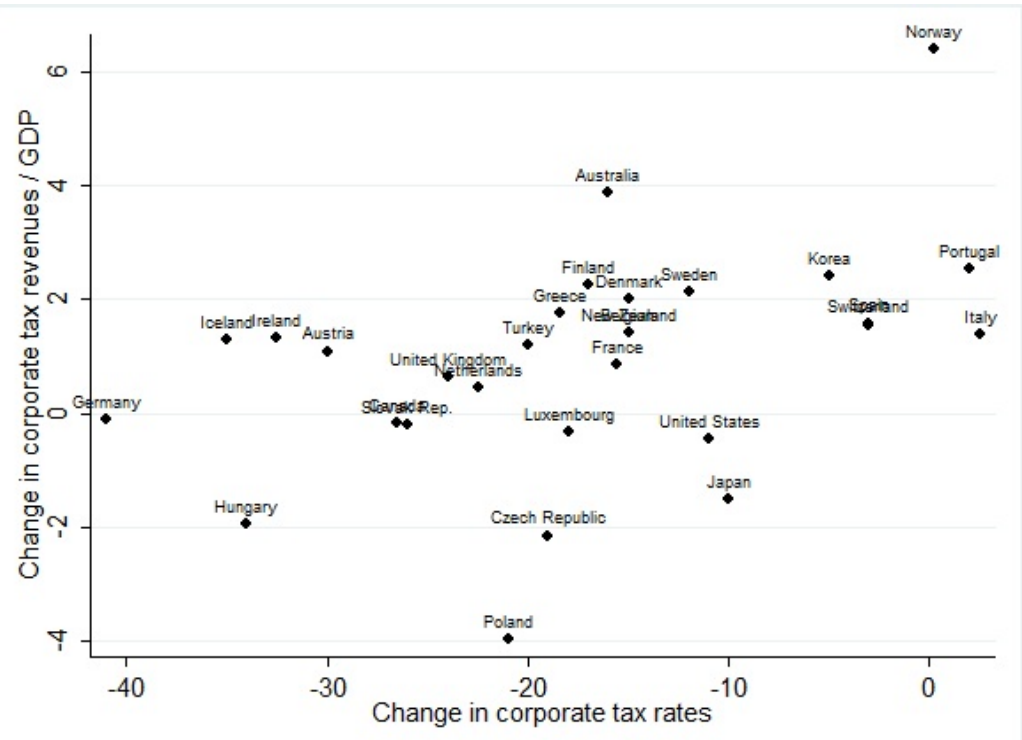

Figure 6: Change in corporate tax rates and change in corporate tax revenues/GDP, 19802008

are the years for which we have data on corporate tax bases. As with corporate tax rates, we observe a (weak) positive relationship between a broadening of the corporate tax base and corporate tax revenues. As mentioned in Section III, we observe that base-broadening measures have more numerous than base-narrowing measures over this period.

Aside from corporate income tax rate schedule non-linearities, which are relatively unimportant, revenue is the product of taxable profit and the tax rate. As we have already investigated the recent changes in the tax rate, it is also useful to consider the development of taxable profit, which we approximate by dividing revenue by the tax rate. Figure 8 shows the average of this taxable profit estimate as a fraction of GDP for each country presented over the period 1980-1990 and 1991-2008. In many countries, there have been substantial changes in the size of taxable profit over these two periods. The most remarkable change has been in Ireland. In the first two decades, Ireland's taxable profit was $2.8 \%$ of GDP; in the second period it was $16.2 \%$. This is consistent with the very low tax rate on profits from manufacturing activity in Ireland, enacted in the early 1980s, which created a powerful incentive for moving real activity and especially taxable profits to Ireland. But many other 


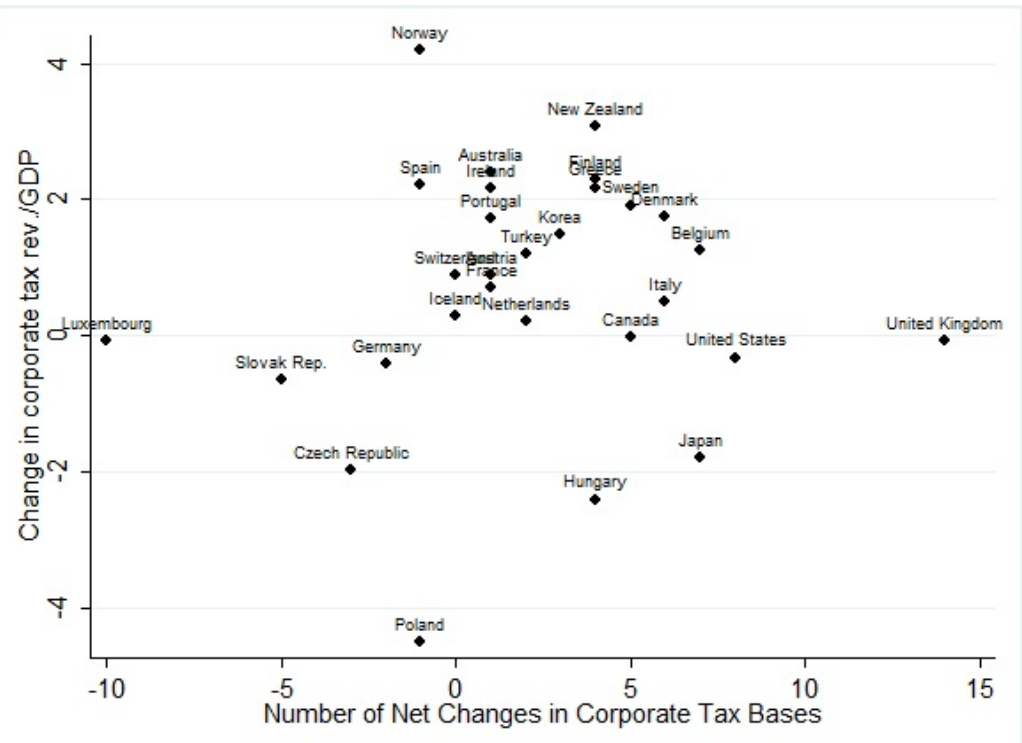

Figure 7: Change in corporate tax bases and change in corporate tax revenues/GDP, 19802004

countries also saw a substantial rise in their taxable profit between the two periods. Taxable profit as a fraction of GDP more than doubled in 15 of the 30 countries examined, and it increased by more than $50 \%$ in seven more ${ }^{19}$

It is interesting to note the experience in the United States, which saw an increase in the ratio of taxable profit to GDP of $41.2 \%$ between the two periods. Commentators in the U.S ${ }^{20}$ have noted that corporate tax revenues have been relatively constant since 1980 , albeit moving strongly with the economic cycle ${ }^{21}$ While this is largely true, this masks the comparison with other OECD countries, as shown in Figure 9. The two series were roughly at the same level in 1980, and although apart for some years in the 1980s when the U.S. taxable profit was lower, they were still at a comparable level until 1995. Since then, however, estimated taxable profits as a fraction of GDP in the rest of the OECD have soared; the GDP-weighted average of the taxable profit to GDP ratio rose from 8.3\% in 1995 to $13.9 \%$ in 2007 , before falling back slightly.

\footnotetext{
${ }^{19}$ For Italy and Japan, however, the corporate profit to GDP ratio decreased between the two periods. ${ }^{20}$ See, for example, Auerbach (2006).

${ }^{21}$ Auerbach and Poterba (1987) investigated the development of U.S. corporate tax revenues up to 1980.
} 


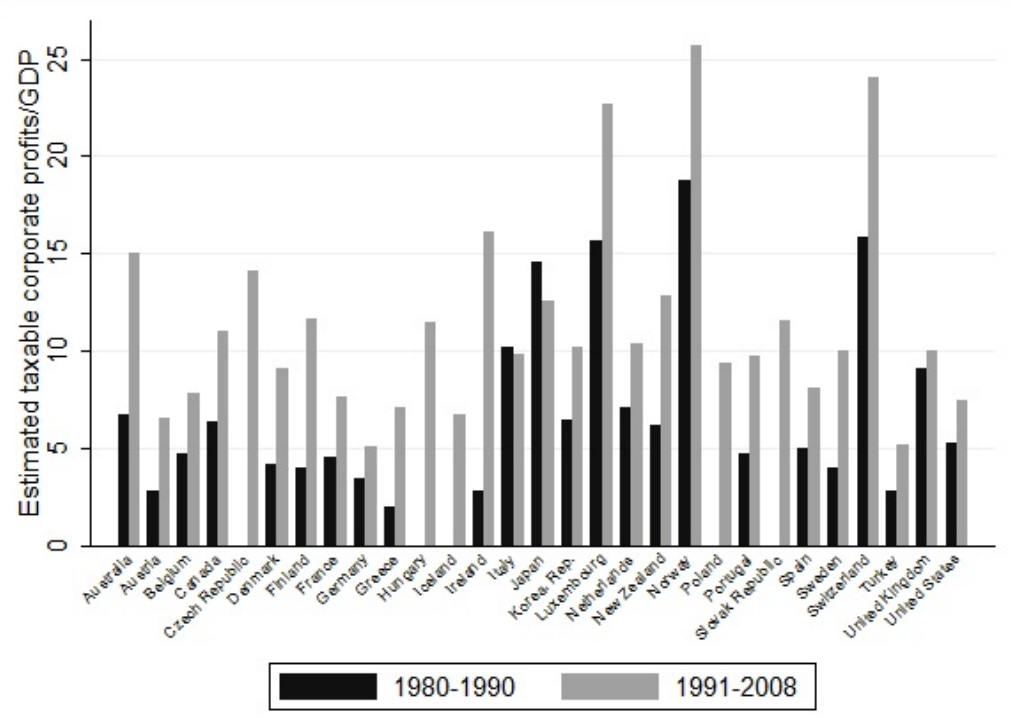

Figure 8: Estimated taxable corporate profits to GDP, by country

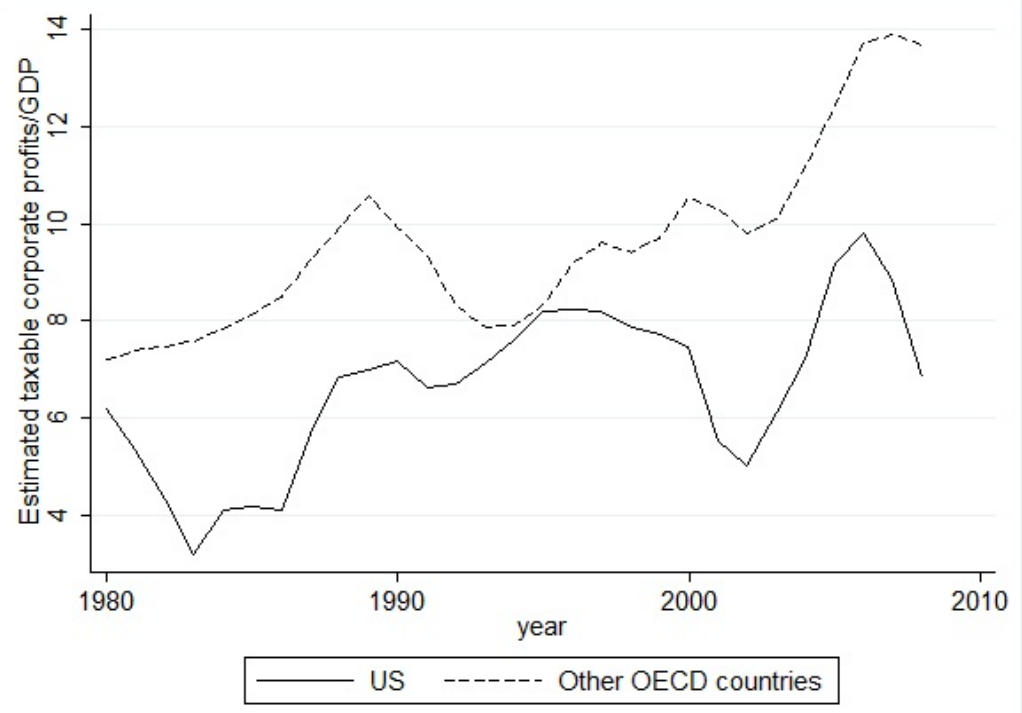

Figure 9: Estimated taxable corporate profits to GDP, U.S. and other OECD countries 


\section{The Correlation Between Tax Base Changes and Tax Rate Changes}

In the previous section, we examined non-parametrically the empirical correlation between the corporate tax rate and corporate tax revenues. Omitted from the discussion thus far are

changes to both the definition and the enforcement of the corporate tax base, which may have an important influence on corporate tax revenues for a given tax rate. Of particular interest for identifying the effect of corporate tax rates on corporate tax revenues is the relationship between the timing of corporate tax rate changes and corporate tax base changes. Over the period considered, most OECD countries have enacted tax policies that have altered the breadth of the corporate tax base. Such policies may be used to encourage business activities, such as increasing certain business tax credits, or to curb tax avoidance behavior by corporations, such as imposing thin capitalization rules. Unfortunately, comprehensive measures of the corporate tax base have not been available, and researchers have had to rely on highly imperfect proxies for the corporate tax base if they address this issue at all.

To overcome this limitation, we utilize our new measures of corporate tax base changes. With our new corporate tax base measures, available from 1980 to 2004, we can examine this relationship in greater detail than has been previously possible. Table 3 provides a crosstabulation of corporate tax base changes by the direction of corporate tax rate changes. We restrict attention to years through 2004 because that is the last date for our tax base measures. For the 29 countries that we examine, there were 167 rate changes (25\% of the 662 country-years for which we have two consecutive years of corporate tax rate data) in either direction. Of these 167, 128 were tax rate decreases and 39 were tax rate increases; the predominance of rate cuts $(77 \%)$ is consistent with the already-discussed trend toward declining corporate statutory rates over this period. Of the 96 country-years when both the tax rate and base changed, the most prevalent combiantion was lower-the-rate, broaden- 
the-base (37 country-years), followed by lower-the-rate, narrow-the-base (31), raise-the-rate, broaden-the-base (17), and lastly raise-the-rate, narrow-the-base (9).

Most tax policy changes that occurred over this period consisted of either changes to the corporate tax rate or the corporate tax base, but not both. This finding is consistent with Becker and Fuest (2011), where the present discounted value of depreciation allowances is the only measure of the tax base considered. We learn that base changes are more likely to occur when there are rate changes compared to when there are no rate changes. About $47 \%$ (60 out of 128) of the corporate tax rate decreases were accompanied by some change to the corporate tax base, while 59\% (23 of 39) of the corporate tax rate increases were accompanied by some change to the corporate tax base. In contrast, some kind of base change occurred in only 40\% (197 out of 495) of the country-years when there was no rate change. A linear probability model that regresses an indicator variable for there being any change to the corporate tax base on an indicator variable for there being any change to the corporate tax rate indicates that this relationship is statistically significant. The probability of any base change increases by nearly 18 percent when there is any change to the corporate tax rate, and this is statistically significant at the $1 \%$ level 22

The nature of the base changes varies depending on whether the tax rate changed, and also whether it was an increase or decrease. Tax rate decreases were slightly more likely to be accompanied by base broadening than base shrinking measures: when there was a tax rate decrease, base broadening measures occurred 29\% (37 out of 128) of the time, while base narrowing measures occurred 26\% (33 out of 128) of the time. Of the 280 instances where there was any change to the corporate tax base, $21 \%$ were accompanied by tax rate decreases (60 of 280 ), while $8 \%$ were accompanied by tax rate increases (23 of 280 ) and $70 \%$ (197 of 280) were for no tax rate change country-years. A t-test on the equality of means reveals that,

\footnotetext{
${ }^{22}$ The estimated coefficient on the indicator for there being any change in the corporate tax rate is 0.177 with a standard error of 0.060 . There are 662 observations in this regression and standard errors are clustered at the country level.
} 
conditional on there being an increase in the corporate tax rate, base-broadening measures are more likely than base-reducing measures at the $5 \%$ level. Conditional on there being a reduction in the corporate tax rate, base-broadening measures are more likely than basereducing measures, but this difference is not statistically significant. Thus, there is no strong tendency on average for base changes to offset, rather than reinforce, the revenue effects of tax rate changes at least within the same year. This result stands in strong contrast to the conventional wisdom that broaden-the-base, lower-the-rate reforms have predominated in recent decades.

For certain base changes some interesting patterns emerge. For example, a crackdown on evasion is much less likely to happen when the rate falls $(11 \%$, or in 14 of the 129 years where there is a tax rate decrease) than when the rate increases $(24 \%$, or 9 or the 38 years where there is a tax rate increase), but least of all when the rate is unchanged (8\%). The most common tax base changes that accompany tax rate decreases are the limitation of loss carry-forward allowances and the strengthening of thin capitalization rules. Tax rate decreases are never associated with extensions to the generosity of the R\&D credit, accelerated depreciation allowances or loss carry back allowances, each of which would be associated with a narrowing of the corporate tax base.

Figure 10 depicts the relationship between changes in the corporate tax rate and the breadth of the corporate tax base. The change in corporate tax rates and base is computed as the change between the last year and the first year in which data are available, as in Figure 6. The majority of the countries in our sample are above the zero horizontal line and to the left of the zero vertical line. This pattern indicates that most countries both lowered their corporate tax rates and engaged in tax policy measures that broadened the corporate tax base more than measures that shrunk the corporate tax base. There is, however, no clear correlation between these two measures.

Figure 11 depicts the relationship between the change in the corporate tax rate and the 


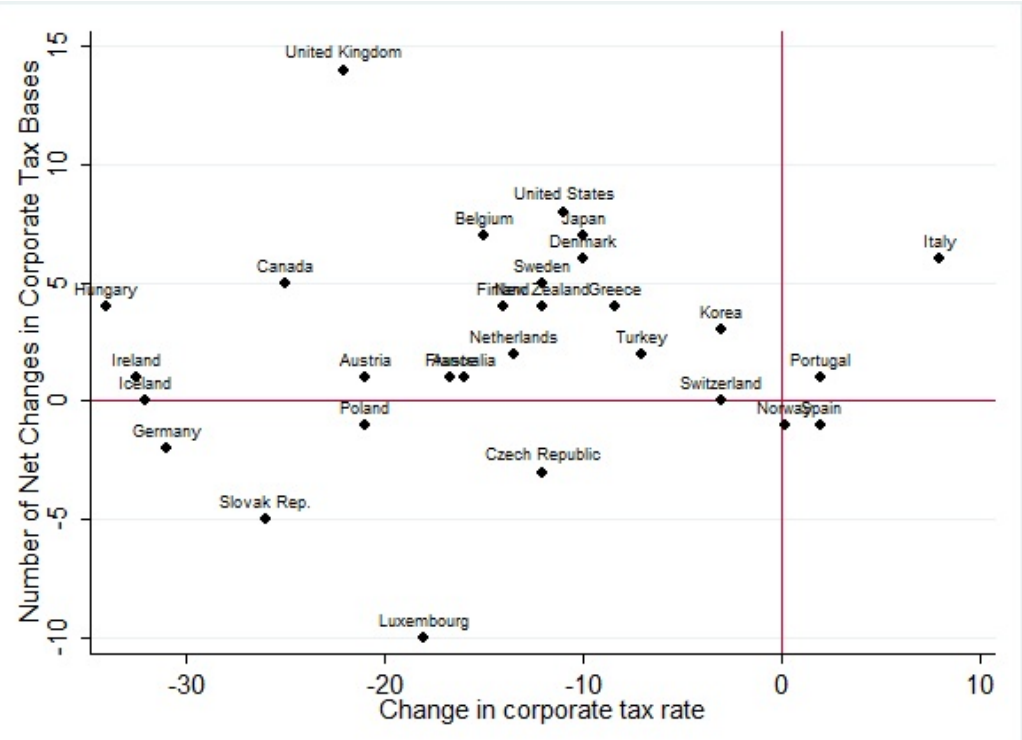

Figure 10: Change in corporate tax rates and change in imputed corporate tax bases

change in the present discounted value of depreciation allowances (PVDA) between the last year and the first year in which the data are available. The PVDA data are from Devereux, Griffith and Klemm (2002), and the change to depreciation allowances corresponds to one of our tax base indicator variables, changes to tax depreciation allowances. This figure provides complementary evidence to Figure 1 in Becker and Fuest (2011), which plots year-to-year changes in corporate tax rates and the PVDA for 19 OECD countries between 1982 and 2003 using the same source data. Becker and Fuest (2011) show that the majority of tax reforms in these country-years resulted in a decrease in the corporate tax rate, a decrease in depreciation allowances (i.e., a broadening of the corporate tax base), or both. In our figure, a similar pattern emerges where the majority of countries have experienced decreases in the corporate tax rate along with a broadening of the corporate tax base (in this case, through a decrease in the PVDA). 


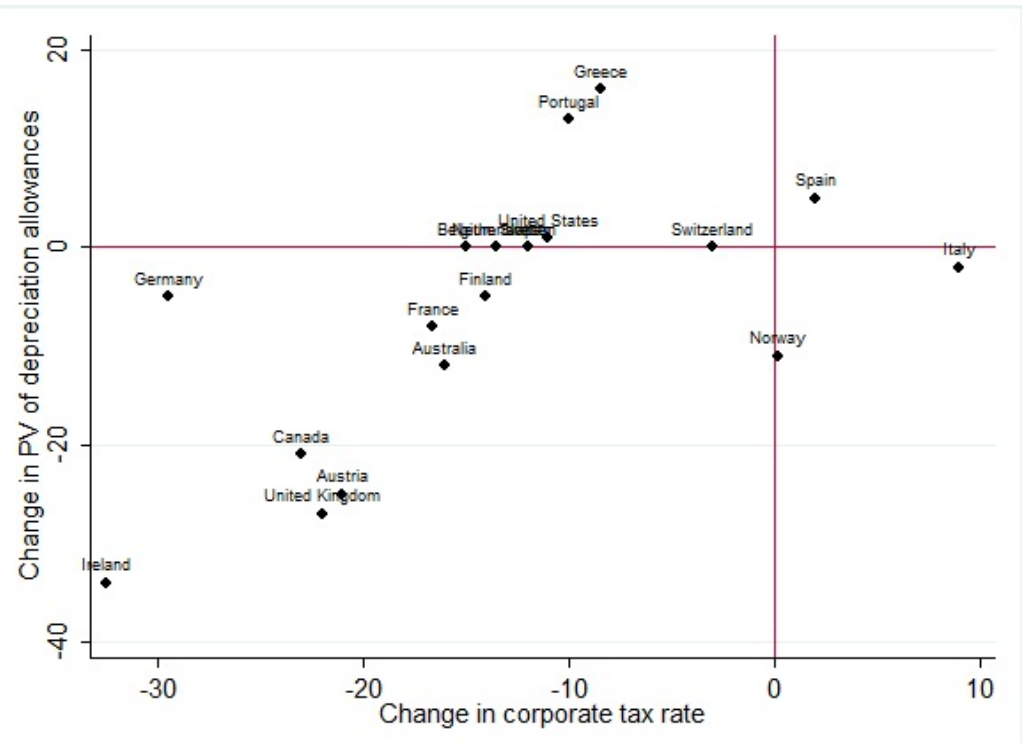

Figure 11: Change in corporate tax rates and change in depreciation allowances, according to Becker and Fuest 2011

\section{Regression Analysis of the Determinanats of Corpo- rate Tax Revenues: Related Research}

Now we turn to a regression-based analysis of the relationship among the corporate tax rate, tax base and tax revenues. We begin by reviewing three previous studies that use countrylevel panel data to estimate the elasticity of corporate tax revenues - and by implication the tax rate elasticity of the corporate tax base - with respect to the statutory corporate tax rate. Devereux (2006) uses data for 20 OECD countries from 1986 to 2004, Clausing (2007) uses data on 29 OECD countries from 1979 to 2002, and Brill and Hassett (2007) use data on 29 OECD countries between 1980 and 2005 .

These studies begin with a regression of corporate tax revenues ${ }^{23}$ as a fraction of GDP ${ }^{24}$

\footnotetext{
${ }^{23} \mathrm{An}$ alternative is to investigate the determinants of the tax base, rather than tax revenue, as shown non-parametrically in Figure 10. The decisive problem with this approach is that the base is not known and can be approximated as $R / t$, which imparts potentially serious "division bias" to the extent of measurement error in $t$.

${ }^{24}$ These analyses, as ours that follows, ignore the possibility that tax rate and tax base changes may affect GDP (indeed that is often their motivation), so that the estimated effects may not reflect solely the impact of the explanatory variables on tax revenues. Nor does this methodology allow us to parse out the effects
} 
on the corporate tax rate, the corporate tax rate squared, and year fixed effects to allow for worldwide macroeconomic conditions to affect all countries' corporate tax system outcomes. ${ }^{25}$ All three studies find a substantial negative response of the tax base to rate changes in their baseline model, implying a revenue-maximizing tax rate ranging from the mid-20s to mid-30s ${ }^{26}$. However, these estimates are quite sensitive to the set of included controls. For example, Clausing's (2007) estimates imply a revenue-maximizing tax rate of $57 \%$ for relatively large, closed countries, such as the U.S. Moreover, in Devereux (2006), the tax rate variables are generally not statistically significant when a larger set of controls is used.

Each of these studies attempts to account for various aspects of the behavioral response to changes in corporate tax rates. Clausing (2007) finds a significantly negative relationship between the top statutory personal tax rate and corporate tax revenues, which is interpreted as evidence of income shifting between the personal and corporate tax bases. In addition, the revenue-maximizing rate is lower for countries that are more integrated in the global economy, measured by having a foreign direct investment-to-GDP ratio that is higher than the median value across OECD countries, presumably because of shifting of corporate income across countries. Devereux (2006) controls for income shifting between the personal and corporate tax bases within a country using the difference between the top personal tax rate and the top corporate tax rate and for income shifting to relatively lower corporate income tax rate countries by including the weighted average of corporate tax rates in the other countries included in his study. However, he does not find strong statistical support for either type of income shifting. Devereux (2006) finds that the average of corporate tax rates in other countries is a statistically significant determinant of corporate tax revenues. This finding suggests that there is income shifting across countries. Brill and Hassett (2007) focus

that operate via the incidence of the tax changes, e.g. that corporate taxes may reduce wage income if they reduce the domestic capital stock.

${ }^{25}$ Despite modeling their analysis on Clausing's (2007) study, Brill and Hassett (2007) appear to not include year fixed effects in their regressions.

${ }^{26}$ Note, however, that in his preferred specification, Devereux's (2006) estimate of the tax rate effect is no longer statistically significant. 
on the evolution of tax responsiveness, and find that the implied revenue-maximizing tax rate has been declining over time.

Critically, all three studies omit country-specific fixed effects, despite using data with a panel structure. If there is unobserved heterogeneity across countries that is related to both the dependent variable, conditional on the observed explanatory variables, and the explanatory variables themselves, the estimates from these studies suffer from omitted-variable bias. Indeed, Gravelle and Hungerford (2007) show that, when country-specific fixed effects are added to this type of specification, corporate tax rates are no longer statistically significant predictors of corporate tax revenues, suggesting two conclusions. First, unobserved heterogeneity indeed imparts bias to the previous analyses based on panel data. Including country-specific fixed effects will, in particular, control for time-invariant aspects of the nonrate aspects of the corporate tax system that may importantly differ across countries. For example, a reduction in the corporate tax rate may induce a larger behavioral response by corporations in a country where the detection of tax avoidance is relatively sophisticated than a similar reduction in a country where firms are able to employ tax avoidance schemes with relative ease. Second, and strikingly, the data do not allow us to reject the null hypothesis that within-country changes in corporate tax rates are not associated with within-country changes in corporate tax revenues.

Even after including country-specific fixed effects, omitted-variable bias will remain if revenue-relevant aspects of the corporate tax system that are not included as explanatory variables vary over time ${ }^{27}$ As previously mentioned, changes to the corporate tax rate often are accompanied by changes to the corporate tax base, and both of these changes affect corporate tax revenues 28 Without accounting for tax base changes, the joint effect of changing rates and bases is attributed to tax rates alone, which in general will lead to

\footnotetext{
${ }^{27}$ Brill and Hassett's (2007) result are more difficult to interpret because no other control variables are included in their regressions.

${ }^{28}$ Robinson and Slemrod (2012) investigate this issue in the context of individual income taxation.
} 
biased estimates of the effect of corporate tax rates on corporate tax revenues. Moreover, the implied revenue-maximizing tax rate from these analyses would be biased toward zero ${ }^{29}$ The analysis of Clausing (2007) and Devereux (2006) include some proxies for the tax base, although we would argue that these measures are not sufficient. Clausing (2007) proxies for the size of corporate profits with the GDP growth rate and the unemployment rate, and proxies for the share of the corporate sector with GDP per-capita 30 Devereux (2006) uses a more direct measure of the corporate tax base-the present discounted value of tax depreciable allowances per dollar of investment in plant and machinery. In contrast to these studies, we construct several variables based on descriptions of tax policy changes to account for changes to the corporate tax base.

\section{Empirical Model and Results}

\subsection{Replications of Previous Studies}

To provide a comparable baseline for our analysis, we begin by estimating using our data the most basic empirical model featured in previous studies:

$$
R_{i t}=\beta_{0}+\beta_{1} \tau_{i t}+\beta_{2} \tau_{i t}^{2}+\mu_{t}+\varepsilon_{i t}
$$

\footnotetext{
${ }^{29}$ Formally, consider that the true model is: $R=\beta_{0}+\beta_{1} \tau+\beta_{2} \tau^{2}+\beta_{3} N+X^{\prime} \gamma+u$. If we estimate the simplest regression model found in earlier studies, we have: $R=\beta_{0}+\beta_{1} \tau+\beta_{2} \tau^{2}+X^{\prime} \gamma+u$ where $u=\beta_{3} N+\nu$. The bias of the estimated coefficients is a function of the covariance between the included variables and the tax base, and $\beta_{3}$. A broader tax base will tend to increase corporate tax revenues, ceteris paribus, so $\beta_{3}>0$. The simultaneity of corporate tax rate decreases and base broadening measures implies that the corporate tax rate and tax base are negatively related. Thus, the estimated tax coefficients are negatively biased. The literature goes one step further to use these biased estimates to compute an implied revenue-maximizing corporate tax rate, computed as $\tau^{*}=-\hat{\beta}_{1} / 2 \hat{\beta}_{2}$. The numerator is biased towards zero because $\beta_{1}>0$ and $\hat{\beta}_{1}$ is negatively biased, whereas the denominator is biased away from zero because $\beta_{2}<0$ and $\hat{\beta}_{2}$ is negatively biased. Thus, the implied revenue-maximizing rates obtained in these studies are biased towards zero.

${ }^{30}$ In another specification, Clausing (2007) includes corporate share of GDP, corporate profitability, and the system for taxing worldwide income (i.e., under a territorial system, a credit system, or a mixture) to account for the tax base.
} 
where $R_{i t}$ is the ratio of corporate tax revenues to GDP, $\tau_{i t}$ is the top statutory corporate tax rate, $i$ denotes country and $t$ denotes year ${ }^{31}$ Year fixed effects, $\mu_{t}$, are included to account for changes in world economic conditions across years. ${ }^{32}$ We include several control variables that are meant to provide a comparison to the key results of Clausing (2007) and Devereux (2006) using the models that include the most generous number of controls. Results from these regressions are shown in Table 6 ${ }^{33}$ Column (1) corresponds to column (4) in Table 4 of Clausing (2007) ${ }^{34}$ Columns (2) and (3) correspond to columns (8) and (9) in Table 1 of Devereux (2006). Both studies include models with interaction terms but omit the level of the non-tax variable, complicating interpretation. In columns (4)-(6), we replicate columns (1)-(3) but also include the level of the relevant non-tax variable. Each specification includes year fixed effects. Standard errors are heteroskedasticity-robust and clustered at the country level to allow for arbitrary within-country serial correlation 35

In addition to corporate tax rates and proxies for the corporate tax base that were described in Section III, there are several other controls included in these studies. Measures to control for incentives to shift corporate profits are included. For example, both studies include some function of the top personal tax rate to account for potential incentives to shift income between corporate and personal tax bases. Devereux (2006) controls for incentives to shift income across corporate tax bases in different countries with the GDP-weighted

\footnotetext{
${ }^{31}$ Following the previous literature, we do not pursue the potential endogeneity of tax policy, nor attempt to distinguish business-cycle-exogenous policy changes, as in Romer and Romer (2012), for example.

${ }^{32}$ Note that Brill and Hassett (2007) do not include year dummies in their analysis.

${ }^{33}$ In the baseline model that includes no other controls, we estimate that $\hat{\beta}_{1}=0.19$ (se $\left.=0.06\right)$ and $\hat{\beta}_{2}=$ $-0.30(\mathrm{se}=0.11)$, which gives an implied revenue maximizing rate of $31.8 \%$. There are 756 observations and standard errors are clustered at the country level. This regression corresponds to the most basic regression that is common to Clausing (2007), Devereux (2006), and Brill and Hassett (2007), and the results we find are broadly similar to these.

${ }^{34}$ We also replicate column (3) of Clausing's (2007) Table 3, which uses the corporate profit rate and corporate share to proxy for the breadth of the corporate tax base. The sample size becomes smaller due to data availability, but the results are fairly stable. The estimated coefficients on the tax variables are both statistically significant and the implied revenue maximizing rate from this regression is 38.2 .

${ }^{35}$ Clausing (2007) and Devereux (2006) compute standard errors that are robust only to heteroskedasticity. Corporate tax revenues are likely serially correlated within a country due to trends in economic growth and the corporate tax climate, among other reasons. Failing to appropriately account for this serial correlation will typically lead to invalid (usually underestimated) standard errors of the parameter estimates.
} 
average of other countries' corporate tax rates. Clausing (2007) instead uses the size and openness of the country ${ }^{36}$ An indicator for whether the country uses a worldwide system in 2004 controls for the system of taxing corporations, either through a tax credit or exemption system 37

Table 6 also provides the implied revenue-maximizing corporate tax rate from these regressions. $\sqrt[38]{38}$ For regressions that include the interaction of the present value of depreciation allowances and the corporate tax rate, we evaluate this revenue maximizing rate at the average value of the present value of depreciation allowances for the estimation sample (0.773) ${ }^{39}$

The results in columns (1)-(4) are qualitatively consistent with the previous studies, although the point estimates differ somewhat due to differences in sample size, years considered, and (possibly) data sources. The relationship between corporate tax revenues and corporate tax rates appears concave and the implied revenue-maximizing corporate tax rate from these regressions falls between 27 and 30 percent, compared to the 33 to 42 percent range in Clausing (2007) and the 16 to 37 percent range found in Devereux (2006). The modified Clausing-style regressions yield results that are fairly consistent with those that do not include the indicators for a country being large or a country being international. In the modified Devereux-style regressions, the results change substantially and the effect of corporate tax rates is no longer statistically significant. The implied revenue maximizing rate is lower, 23 and 15 percent, but should not be weighed heavily because of the imprecision of

\footnotetext{
${ }^{36}$ Two dummy variables are separately interacted with the corporate tax rate and corporate tax rate squared. The first is an indicator for whether the country has an above average population. The second is an indicator for whether the country has an above average foreign direct investment stock to GDP ratio. We construct this measure on a year-by-year basis so it varies within country over time.

${ }^{37}$ We determine the type of system that is in place using PricewaterhouseCoopers' Corporate Taxes: $A$ Worldwide Summary 2004 publication.

${ }^{38}$ This rate is computed by solving the first-order condition of the corporate tax revenue regression equation with respect to the corporate tax rate. For ease of reading, the corporate tax rate squared is divided by 100 in the regressions. Thus, for example, the implied revenue-maximizing rate is computed as $-1 * \hat{\beta}_{\tau} /\left(2 * \hat{\beta}_{\tau^{2}} / 100\right)$ in the baseline model.

${ }^{39}$ Note that in Clausing (2007) and Devereux (2006), the revenue-maximizing tax rate is computed ignoring that some of the control variables are a function of the corporate tax rate. The rate is computed as though it came from the baseline model.
} 
these estimates.

These regression results do not uncover any evidence of income shifting, either between the corporate and personal income tax base within a country or between corporate tax bases across countries. We should note that our ability to identify income shifting across countries is limited because we include only the tax rates for the other countries included in this study, as is done in the previous literature. Thus, this measure does not separately measure incentives to shift to tax havens 40 The only factors that appear to consistently have a statistically significant effect on corporate tax revenues are the type of tax system (a worldwide system reduces revenues), the unemployment rate (reduces revenue), and the size of the country as proxied by population 41

Having verified that we derive similar conclusions as these previous studies using their methodology, we turn now to address several problematic econometric issues.

\subsection{Country-specific fixed effects}

As already noted, excluding country-specific fixed effects generates biased estimates in the presence of unobserved heterogeneity across countries that is correlated with corporate tax rates and affect corporate tax revenues ${ }^{42}$ A potential source of such heterogeneity are differences in corporate tax environments, such as in the willingness to rely on corporations for tax revenues or in the effectiveness of tax collection agencies. Another source of heterogeneity is in the data collection systems. Some of these omitted variables likely affect both

\footnotetext{
${ }^{40}$ Desai, Foley and Hines (2003) provide evidence on the behavioral responses of U.S. firms' foreign direct investment to international tax rates and Altshuler and Grubert (2004) provide evidence on responses in a larger set of countries. Both report a large tax elasticity of foreign investment. Desai, Foley and Hines (2006b) develop a model where tax havens may increase business activity in non-haven countries, with empirical support in Desai, Foley and Hines (2006a).

${ }^{41}$ Note that the GDP growth rate, GDP per capita, and international variables appear to be statistically significant if standard errors are not clustered. This would more closely mimic the results shown in Clausing (2007).

${ }^{42}$ We do not believe there is no insight at all to be gained from cross-country comparisons. There is no doubt, for example, that Ireland's relatively low corporate tax rates are partly responsible for its large corporate tax revenues relative to its GDP. We leave for future research the appropriate way to learn from this with minimal bias in estimated causal relationships.
} 
corporate tax revenues and corporate tax rates, rendering the previous estimates biased and inconsistent.

Gravelle and Hungerford (2007) show that the significance of the estimated tax effects in these models may be quite sensitive to the inclusion of country fixed effects. To investigate this issue further, we refine the estimates from Section 6.1 by adding country-specific fixed effects to the estimating equations. Because the indicator for corporations being taxed on worldwide income is time-invariant in our data, this variable is now excluded. We also include additional controls for several other factors that may importantly affect corporate tax revenues. For one, the extent of integration between the corporate and personal income tax systems may influence the responsiveness of corporate tax revenues. To account for this, we include indicator variables for the type of dividend tax system in place in a country, whether classical method or imputation method. Systems that combine aspects of the classical and imputation methods are the excluded category. Second, the size of the financial sector may influence corporate tax receipts as financial sector profits may be more easily manipulated due to corporate activity being intangible-intensive. We proxy for the size of the financial sector with the ratio of central banking assets to GDP. These additional variables are included in the remainder of our analysis.

Table 7 shows that, when country-specific fixed effects are added to the model, in only two specifications do corporate tax rates appear as even marginally significant determinants of corporate tax revenues. Thus, unobserved cross-country factors appear to be important determinants of the estimated effect of corporate tax rates on corporate tax revenues using cross-country data. Within countries, however, no clear relationship appears. Although the estimated tax effects are generally not statistically significant, Table 7 also includes the implied revenue-maximizing tax rate from these regressions. Again, for specifications that include the present value of depreciation allowances, we evaluate these rates at the mean of this variable. For those regressions that control for the personal income tax system, the 
implied revenue-maximizing rate falls between 28 and 37 percent, somewhat higher than that when country-specific fixed effects are excluded. When we do not control for the top personal income tax rate, the implied revenue maximizing rate is much higher, likely implausibly high.

Interestingly, in the fixed-effects specification there is now evidence of some income shifting 43 Increases in the top personal tax rate are significantly related to an increase in corporate tax revenues, perhaps indicating that income is shifted from corporations to individuals when the corporate tax rate increases. This finding is consistent with the corporate tax acting as a backstop to the personal income tax. However, the effect of an increase in the corporate tax rate in other countries has the "wrong" sign if these increases would lead to corporate income being sheltered in the home country. Instead, it is the international intensity of an economy rather than the size of the economy that now matters (although only marginally) for corporate tax revenues. The ratio of central banking assets to GDP, meant to proxy for the size of the financial sector in an economy, is negatively related to corporate tax revenues. This is the relationship that we would expect if manipulating profits is relatively easier in the financial sector. We also see that the integration of the personal and corporate tax is an important factor, as dividend tax policy is a significant determinant of corporate tax revenues relative to GDP.

\subsection{The Impact of the Corporate Tax Base}

As we have previously argued, the definition and enforcement of the corporate tax base is a theoretically important determinant of corporate tax revenues. However, because legislation that determines these factors is highly complex, it is difficult to obtain a summary measure of the corporate tax base and, perhaps for this reason, it has been largely ignored in empirical analysis. Moreover, we have documented that aspects of the corporate tax base often change, so that even after accounting for persistent differences in tax policy across countries, as in

\footnotetext{
${ }^{43}$ Gravelle and Hungerford (2007) do not account for income shifting in their replications that include country-specific fixed effects.
} 
the country-fixed effects regressions, estimates of the tax-rate responsiveness of corporate tax revenues are likely to remain biased. Our new measures of corporate tax base changes allow us to provide estimates of the relationship between corporate tax revenues and corporate tax rates that more plausibly control for changes to the corporate tax base.

Ideally, we would like to have a direct measure of the breadth of the corporate tax base and for simplicity, assume that this could be summarized by a single variable, $b$. With such a measure, we would like to include it directly in our previous regressions as follows:

$$
R_{i t}=\beta_{0}+\beta_{1} \tau_{i t}+\beta_{2} \tau_{i t}^{2}+\beta_{3} b+\beta_{4}\left(\tau_{i t} \times b\right)+\beta_{5}\left(\tau_{i t}^{2} \times b\right)+X^{\prime} \xi+\mu_{t}+\gamma_{i}+\varepsilon_{i t}
$$

where $\beta_{3}$ provides the estimated impact of a one unit increases in the "breadth" of the tax base, and $\beta_{4}$ and $\beta_{5}$ provide the estimated impact of the interaction between the corporate tax rate and corporate tax base. Recall, however, that our new tax base measures reflect changes in the corporate tax base, rather than the tax base itself. That is, when the R\&D tax credit amount is increased (so $\Delta b<0$ ), the change in $b$ is recorded as -1 in our data. To accommodate this aspect of our data, we must redefine our model in first differences as follows:

$$
\Delta R_{i t}=\alpha_{1} \Delta \tau_{i t}+\alpha_{2} \Delta \tau_{i t}^{2}+\alpha_{3} B_{i t}+\alpha_{4} \Delta \tau_{i t} B_{i t}+\alpha_{5} \Delta \tau_{i t}^{2} B_{i t}+\Gamma \Delta X_{i t}+\mu_{t}+\nu_{i t}
$$

where $B_{i t}$ is a vector of indicator variables that identify changes to the tax base. As defined in Section 2, these variables are set equal to +1 when there is a change in tax policy that broadens the corporate tax base, and are set equal to -1 when there is a change in tax policy that narrows the corporate tax base. These measures enter directly into equation 4 because they are measured as differences. Unobserved cross-country heterogeneity that is time-invariant is now removed through first-differencing, rather than via a country-specific fixed effect as in the previous section. Thus, this specification is similar in spirit to that of 
Table (5), with the addition of the base variables.

Table 8 provides regression results where we include an indicator variable that equals one only when any base broadening measures were implemented, and an indicator variable that equals one only when any base narrowing measures were implemented. ${ }^{44}$ Because we noted earlier that some countries have implemented tax policies that contain measures to both broaden the tax base and to reduce the tax base in a given year, both of these indicator variables could be equal to one for a given observation. In some specifications, we also include the interaction between the change in corporate tax rates and these aggregate base change measures. We lose several observations through this specification because the firstdifferencing requires that we have data for all included variables in consecutive years for that observation to be included in the model. In addition, we lose the first observation for each country. The specifications also include control variables that are time-varying in first-differences. As before, the standard errors reported are clustered at the country level.

Overall, these regressions do not allow us to reject the null hypothesis that a change in corporate tax rates has no effect on corporate tax revenues. Given the lack of a tax rate effect found in the country-fixed-effects regressions, it is not surprising that the coefficients on the corporate tax rate variables here are not statistically significant, as both identify this effect from within-country changes. We do, though, find evidence of profit shifting across countries. As the weighted average of corporate tax rates in other countries falls, there is a statistically significant decrease in corporate tax revenues in a country. Country-specific macroeconomic factors are also found to be important, as there is a strong negative relationship between changes in unemployment rates and changes in corporate tax revenues relative to GDP.

The final specifications (4) and (5), which include interaction terms and other macroeconomic factors, indicate that, as expected, tax policy changes that broaden the corporate

\footnotetext{
${ }^{44}$ This procedure does not account for the relative importance of the various types of base broadeners in the absence of a defensible and data-feasible weighting approach that would apply across countries and years. Below we investigate the effect of base changes within each category separately, but even this begs the question of comparability within a category across countries and years.
} 
tax base are associated with increases in corporate tax revenues. This specification also indicates that the interaction between the change in the corporate tax rate and the tax rate squared and tax-base-narrowing measures is statistically significant at the $10 \%$ level, although each tax rate variable does not have a significant level effect. Intuitively, when there are reductions to the corporate tax rate and the base to which the rate is applied becomes narrower, corporate tax rates fall. However, the coefficient on the interaction between the corporate tax rate squared and the indicator for a base-narrowing measure indicates that this effect becomes smaller with larger changes in corporate tax rates. The point estimates suggest that a decrease in the corporate tax rate when there are also base-broadening policy measures is associated with an increase in corporate tax revenues. While this effects is not statistically significant, this result is consistent with the conventional wisdom that policies that reduce the corporate tax rate while broadening the corporate tax base broadening measures have been constructed in a way to generate additional corporate tax revenues. All in all, there is not clear evidence for the hypothesis that a broader tax base reduces tax rates responsiveness.

To examine the impact of each of our new tax base measures separately, Table 9 provides regression results where we include variables that indicate that there was a change in each tax base measure separately. Each base change variable may take on a value of +1 or -1 , depending on the direction of change. In column (1), we include only the tax base measures, and in column (2) we include changes to other factors as additional controls. In specifications (1) and (2), we are implicitly assuming that the effect of an increase to some measure of the corporate tax base on corporate tax revenues is the same in magnitude as a decrease in that measure on corporate tax revenues, though opposite in sign. To allow base broadening and base narrowing changes to have different impacts on corporate tax revenues, columns (3a)-(3b) present the results of a regression that includes for each tax base measure an indicator variable for the tax base measure being equal to +1 and an indicator variable for 
the tax base measure being equal to -1 . The variables in column (3a) are in first differences. As previously discussed, the effect of corporate tax rates on corporate tax revenues may change with changes to the corporate tax base. In columns (4a)-(4c), we present the results of a regression that includes as independent variables the tax base measures (defined by the $\{-1,0,1\}$ method) and their interactions with the change in corporate tax rate variables, along with the additional control variables. Column (4a) provides the parameter estimates of the level effects, column (4b) provides the parameter estimates of the tax base measures interacted with the change in the corporate tax rate, and column (4c) provides parameter estimates of the tax base measures interacted with the change in the squared corporate tax rate.

Several interesting patterns emerge. One surprising result is that implementing or strengthening thin capitalization rules is associated with decreases in corporate tax revenues, although this effect is only marginally significant. The statistical significance of this relationship disappears when the thin capitalization variable is interacted with the change in the corporate tax rate. Reductions to or the elimination of the R\&D credit (indicated by the R\&D indicator being set equal to +1 ) appears to increase corporate tax revenues. This result is expected as a reduction in a tax credit should increase tax liabilities, ceteris paribus. However, this short-term increase in revenues may be at least partially offset in the future due to foregone research and development opportunities. While the taxation of foreign corporations is not statistically significant when entered into the model directly, this masks an asymmetry in responses depending on the direction of the change. A reduction in the degree to which foreign corporations are taxed corresponds to an increase in corporate tax revenues. This relationship is expected if these types of policies are successful at attracting foreign investment, as many policy descriptions indicate. An extension or expansion to loss carry-forward allowances is associated with an increase in corporate tax revenues, although this effect is only marginally significant. None of the other tax base measures is individually 
statistically significant in the level specifications.

In the specification that includes interaction terms between changes in the corporate tax rate and the tax base measures, 4(b), other tax base measures appear to be important. Measures that increase the tax liabilities of foreign entities are associated with increases in corporate tax revenues. This relationship is intuitive; the increased taxation of foreign entities often reflects an extension of the definition of a resident company for corporate income tax purposes. Thus, this broadening of the set of corporations that are subject to the corporate income tax increases tax revenues, at least in the contemporaneous period. A surprising result is that an increase in credits for foreign taxes paid is associated with an increase in corporate tax revenues, though this relationship is concave.

The impact of a tax rate or tax base change may not happen immediately, as businesses may take time to adjust to new tax policy. In addition, corporations may make adjustments to their business policies in anticipation of future legislative changes that have been passed but not yet enacted. To explore the potential dynamics of responses, Table 10 provides regression results that include a lead and a lag of the tax rate and tax base measures. The first column provides parameter estimates for the variables when the contemporaneous values are entered, the second column provides the lagged values, while the third provides the parameter estimates when values are computed one year ahead.

As we have seen before, once we account for time-invariant heterogeneity across countries and changes to the corporate tax base, we do not find compelling evidence of a strong behavioral response of corporate tax revenues to the statutory tax rate. The relationship between changes to the corporate tax rate and changes to corporate tax revenues relative to GDP are not statistically significant. There is some evidence of responses to changes in the corporate tax base, some of which vary over time. The strengthening of thin capitalization rules is again associated with decreases in corporate tax revenues both in the year that the rules are enhanced and in the following year. Previously (see Table 91, we found that the 
enhanced taxation of foreign companies led to an increase in corporate tax revenues. Now, when we allow the effect of the treatment of foreign corporations to change over time, we see that this effect may be driven by intertemporal income shifting. The negative relationship between a future enhancement in the taxation of foreign corporations and corporate revenues implies that foreign corporations may shift their profits away from a country in anticipation of an increased tax burden. The positive relationship between reductions to the R\&D credit and corporate tax revenues is no longer statistically significant, although the magnitude of the effect is roughly the same. Thus, there may be some intertermporal shifting of corporate profits because of the $R \& D$ credit, although this is not strongly supported at least in a two-year window.

Our results from models that incorporate new measures of changes to the corporate tax base provide further evidence that the large behavioral response of corporate tax revenues (relative to GDP) to corporate tax rates found in the previous literature likely results from spurious correlation between these two variables. Thus, arguments that corporate tax revenues could be increased by lowering the statutory corporate tax rate without any adjustments to the breadth of the corporate tax base are flawed. The complexity of the legislation of corporate tax policy has made it difficult to identify a comprehensive measure of the corporate tax base for studies on corporate taxation, and previous studies have had to use only loose proxies for the corporate tax base. Using our newly constructed measures of changes to the corporate tax base, we find that certain aspects of the corporate tax base, namely the treatment of foreign corporations and the generosity of the R\&D credit, significantly impact corporate tax revenues.

Although our analysis provides a step towards a better understanding of the nature of the effect of corporate tax rates and corporate tax bases on corporate tax revenues, it is limited by these measures being indicator variables that do not account for their quantitative importance. Ideally, we would like to have continuous measures of each of these components 
of the corporate tax base in levels that are comparable across countries to provide an indepth analysis of the interaction between corporate tax rate and these different aspects of the corporate tax base over time, and how these have translated into changes in corporate tax revenues.

\section{Conclusions}

Citing previous studies of the responsiveness of the corporate tax base to the corporate tax rate, some have argued that corporate tax revenues could be increased in the U.S. by cutting the tax rates. In this paper, we first corroborate the findings of Gravelle and Hungerford (2007) that the statistical relationship does not survive when only within-country changes are studied, thus eliminating spurious correlation due to unobserved country-specific effects on both tax rates and revenue. Next, we note that an important aspect of the corporate tax system, the breadth of the corporate tax base, has been largely ignored in these studies due to data limitations, causing previous estimates to suffer from an additional bias. To address this issue, we have compiled a new database that documents changes to key components of the corporate tax base definition and enforcement, and calculate the relationship between changes to the corporate tax rate and changes to the corporate tax base. To our knowledge, this is the first systematic analysis of this relationship. We discover that the conventional wisdom that tax rate decreases are generally accompanied by base-broadening reforms is only weakly evident in the data.

Finding that changes to the corporate tax rate are often coupled with changes to the corporate tax base, we re-estimate the relationship between the corporate tax rate and corporate tax revenues, taking into account changes to the corporate tax base. We find that correcting for omitted variable bias, corporate tax rates no longer have a statistically significant relationship with corporate tax revenues. We do find evidence that tax policies 
that broaden the tax base are associated with increases in corporate tax revenues. However, it is difficult to link particular corporate tax base changes to changes in tax revenue, perhaps in part because the short-term revenue response of increased investment is generally negative. Future research should endeavor to estimate these mechanisms more accurately. 


\section{References}

Altshuler, Rosanne and Harry Grubert, "Taxpayer Responses to Competitive Tax Policies and Tax Policy Responses to Competitive Taxpayers: Recent Evidence," Tax Notes International, 2004, 34, 1349-1362.

Auerbach, Alan, "Who Bears the Corporate Tax? A Review of What We Know," in James Poterba, ed., Tax Policy and the Economy, Vol. 20, MIT Press, 2006, pp. 1-40.

and James Poterba, "Why Have Corporate Tax Revenues Declined?," in Lawrence Summers, ed., Tax Policy and the Economy, Vol. 1, MIT Press, 1987, pp. 1-28.

Beck, Thorston, Asli Demirguc-Kunt, and Ross Levine, "A New Database on Financial Development and Structure," World Bank Economic Review, 2000, 14, 597-605.

Becker, Johannes and Clemens Fuest, "Optimal Tax Policy when Firms are Internationally Mobile," International Tax and Public Finance, 2011, 18, 580-604.

Brill, Alex and Kevin Hassett, "Revenue-Maximizing Corporate Income Taxes: The Laffer Curve in OECD Countries," 2007. AEI Working Paper No. 137.

Chetty, Raj, "Is the Taxable Income Elasticity Sufficient to Calculate Deadweight Loss? The Implications of Evasion and Avoidance," American Economic Journal: Economic Policy, 2009, 1 (2), 31-52.

Clausing, Kimberly, "Corporate Tax Revenues in OECD Countries," International Tax and Public Finance, 2007, 14, 115-133.

Desai, Mehir, C. Fritz Foley, and James Hines Jr., "Chains of Ownership, Tax Competition, and the Location Decision of Multinational Firms," in H. Herrmann and R. Lipsey, eds., Foreign Direct Investment in the Real and Financial Sector of Industrial Countries, Springer-Verlag, 2003, pp. 61-98. 
_ _ _ a a _ _ _ "The Demand for Tax Haven Operations," Journal of Public Economics, 2006, $90(3), 513-531$.

Desai, Mihir, C. Fritz Foley, and James Hines Jr., "Do Tax Havens Direct Economic Activity?," Economic Letters, 2006, 90, 219-224.

Devereux, Michael, "Developments in the Taxation of Corporate Profit in the OECD Since 1965: Rates, Bases, and Revenues," 2006. Mimeo.

and Rachel Griffith, "Evaluating Tax Policy for Location Decisions," International Tax and Public Finance, 2003, 10, 107-126.

_ _ _ _ and Alexander Klemm, "Corporate Income Tax Reforms and International Tax Competition," Economic Policy, 2002, 35, 451-495.

Feldstein, Martin, "The Effect of Marginal Tax Rates on Taxable Income: A Panel Study of the 1986 Tax Reform Act," Journal of Political Economy, 1995, 103, 551-572.

Gordon, Roger and Joel Slemrod, "Are 'Real Responses to Taxes Simply Income Shifting between Corporate and Personal Tax Bases?," in Joel Slemrod, ed., Does Atlas Shrug? The Economic Consequences of Taxing the Rich, Russell Sage Foundation, 2002, pp. 240-280.

Gravelle, Jane and Thomas Hungerford, "Corporate Tax Reform: Issues for Congress," 2007. Congressional Research Service Report RL34229.

Gruber, Jonathan and Joshua Rauh, "How Elastic is the Corporate Income Tax Base?," in Alan Auerbach, James Hines, Jr., and Joel Slemrod, eds., Taxing Corporate Income in the 21st Century, Cambridge University Press, 2007, pp. 140-163.

Hall, Robert and Dale Jorgenson, "Tax Policy and Investment Behavior," The American Economic Review, 1967, 57 (3), 391-414. 
International Bureau of Fiscal Documentation, Annual Report-International Bureau of Fiscal Documentation, International Bureau of Fiscal Documentation, 1980-2004.

Kopczuk, Wojciech, "Tax Bases, Tax Rates and the Elasticity of Reported Income," Journal of Public Economics, 2005, 89, 2093-2119.

Robinson, Leslie and Joel Slemrod, "Understanding Multidimensional Tax Systems," International Tax and Public Finance, 2012, 19 (2), 237-267.

Romer, Christina and David Romer, "A Narrative Analysis of Interwar Tax Changes," 2012. University of California Working Paper.

Saez, Emmanuel, "The Effect of Marginal Tax Rates on Income: A Panel Study of 'Bracket Creep'," Journal of Public Economics, 2003, 87, 1231-1258.

, Joel Slemrod, and Seth Giertz, "The Elasticity of Taxable Income with Respect to Marginal Tax Rates: A Critical Review," Journal of Economic Literature, 2012, 50, $3-50$.

Slemrod, Joel, "Methodological Issues in Measuring and Interpreting Taxable Income Elasticities," National Tax Journal, 1998, 51 (4), 773-788.

and Wojciech Kopczuk, "The Optimal Elasticity of Taxable Income," Journal of Public Economics, 2002, 84 (1), 91-112. 
Table 1: Summary Statistics

\begin{tabular}{lccccc}
\hline \hline & & & & & \\
& Mean & Std Dev & Min. & Max. & N \\
\hline Corp. tax revenues/GDP & 2.9 & $(1.6)$ & 0.3 & 12.9 & 775 \\
Corporate tax rate & 34.0 & $(9.7)$ & 8.5 & 56.0 & 778 \\
Personal tax rate & 44.3 & $(14.3)$ & 7.0 & 93.0 & 765 \\
Classical dividend tax system & 0.3 & $(0.5)$ & 0.0 & 1.0 & 812 \\
Imputation dividend tax system & 0.3 & $(0.5)$ & 0.0 & 1.0 & 812 \\
Mixed dividend tax system & 0.0 & $(0.1)$ & 0.0 & 1.0 & 812 \\
Other dividend tax system & 0.1 & $(0.3)$ & 0.0 & 1.0 & 812 \\
PDV of depreciation allowance & 0.8 & $(0.1)$ & 0.6 & 1.0 & 482 \\
GDP per capita & 20527.2 & $(14981.8)$ & 1114.0 & 117954.7 & 824 \\
GDP growth rate & 2.8 & $(2.7)$ & -14.6 & 11.5 & 814 \\
Population growth rate & 0.6 & $(0.5)$ & -0.6 & 2.5 & 841 \\
Urban population percentage & 72.7 & $(11.8)$ & 42.8 & 97.4 & 841 \\
Unemployment rate & 7.4 & $(4.0)$ & 1.5 & 23.9 & 726 \\
Profit rate & 0.4 & $(0.1)$ & 0.2 & 0.5 & 291 \\
Corporate share & 0.6 & $(0.1)$ & 0.3 & 0.7 & 293 \\
FDI stock/GDP & 0.4 & $(1.0)$ & 0.0 & 10.1 & 759 \\
FDI flow/GDP & 0.1 & $(0.3)$ & -0.6 & 5.6 & 765 \\
Central bank assets/GDP & 0.1 & $(0.1)$ & 0.0 & 0.9 & 760 \\
Stock market cap./GDP & 0.6 & $(0.6)$ & 0.0 & 4.3 & 583 \\
\hline Observations & 841 & & & & \\
\hline \hline
\end{tabular}

Sources discussed in Section III of the text. 
Table 2: Frequency of tax base changes

\begin{tabular}{|c|c|c|c|c|}
\hline & & -1 & +1 & 0 \\
\hline$R \& D$ credit & & 16 & 4 & 705 \\
\hline Foreign tax credit & & 14 & 7 & 704 \\
\hline Foreign company taxation & & 21 & 16 & 688 \\
\hline Evasion & & 0 & 78 & 647 \\
\hline Investment credit & & 36 & 18 & 671 \\
\hline Accelerated depreciation & & 22 & 9 & 694 \\
\hline Loss carry back & & 7 & 1 & 717 \\
\hline Loss carry forward & & 18 & 8 & 699 \\
\hline Thin capitalization rules & & 0 & 19 & 705 \\
\hline CFC legislation & & 0 & 14 & 711 \\
\hline Other rate changes & & 36 & 40 & 649 \\
\hline Other broadening measures & & 15 & 34 & 676 \\
\hline Total & & 185 & 248 & 291 \\
\hline Any base broadeners & 190 & & & \\
\hline Any base narrowers & 145 & & & \\
\hline Any base change & 289 & & & \\
\hline No base changes & 436 & & & \\
\hline
\end{tabular}

Source: Authors' compilation of information from IBFD Annual Reports, 1980-2002, 2004.

Note: Country-years may have both base-broadeners and basenarrowers, so the number of country-years with any base change is less than the number of country-years with base-broadeners plus the number of country-years with base-narrowers. 
Table 3: Frequency of tax base changes accompanying rate changes

\begin{tabular}{|c|c|c|c|c|c|c|c|c|}
\hline Change in corporate tax rate & \multicolumn{2}{|c|}{ Decrease } & \multicolumn{2}{|c|}{ Increase } & \multicolumn{2}{|c|}{ No change } & \multicolumn{2}{|c|}{ Total } \\
\hline Change in corporate tax base measure & -1 & +1 & -1 & +1 & -1 & +1 & -1 & +1 \\
\hline R\&D credit & 3 & 0 & 0 & 1 & 12 & 3 & 15 & 4 \\
\hline Foreign tax credit & 1 & 2 & 2 & 0 & 9 & 5 & 13 & 7 \\
\hline Foreign company taxation & 4 & 1 & 2 & 1 & 11 & 12 & 17 & 14 \\
\hline Evasion & 0 & 14 & 0 & 9 & 0 & 53 & 0 & 67 \\
\hline Investment credit & 4 & 2 & 3 & 0 & 28 & 15 & 35 & 17 \\
\hline Accelerated depreciation & 4 & 0 & 1 & 1 & 16 & 8 & 21 & 9 \\
\hline Loss carry back & 3 & 0 & 0 & 0 & 4 & 1 & 7 & 1 \\
\hline Loss carry forward & 5 & 1 & 0 & 0 & 12 & 7 & 17 & 8 \\
\hline Thin capitalization rules & 0 & 7 & 0 & 1 & 0 & 11 & 1 & 19 \\
\hline $\mathrm{CFC}$ legislation & 0 & 5 & 0 & 2 & 0 & 7 & 0 & 14 \\
\hline Other rate changes & 10 & 4 & 3 & 2 & 20 & 28 & 33 & 34 \\
\hline Other broadening measures & 7 & 10 & 0 & 4 & 7 & 19 & 14 & 33 \\
\hline Total & 41 & 54 & 11 & 21 & 107 & 172 & 143 & 230 \\
\hline Change in corporate tax rate & \multicolumn{2}{|c|}{ Decrease } & \multicolumn{2}{|c|}{ Increase } & \multicolumn{2}{|c|}{ No change } & \multicolumn{2}{|c|}{ Total } \\
\hline Base broadened $(+1)$ & \multicolumn{2}{|c|}{37} & \multicolumn{2}{|c|}{17} & \multicolumn{2}{|c|}{132} & \multicolumn{2}{|c|}{186} \\
\hline Base narrowed $(-1)$ & \multicolumn{2}{|c|}{33} & \multicolumn{2}{|c|}{9} & \multicolumn{2}{|c|}{96} & \multicolumn{2}{|c|}{135} \\
\hline Any base change & \multicolumn{2}{|c|}{60} & \multicolumn{2}{|c|}{23} & \multicolumn{2}{|c|}{197} & \multicolumn{2}{|c|}{280} \\
\hline No base change & \multicolumn{2}{|c|}{68} & \multicolumn{2}{|c|}{16} & \multicolumn{2}{|c|}{299} & \multicolumn{2}{|c|}{383} \\
\hline Total rate changes & \multicolumn{2}{|c|}{129} & \multicolumn{2}{|c|}{38} & \multicolumn{2}{|c|}{495} & \multicolumn{2}{|c|}{662} \\
\hline
\end{tabular}

Source: Authors' compilation of information from IBFD Annual Reports, 1980-2002, 2004.

Note: There are only 662 country-years here, compared to 725 in Table 2 because the data are missing some consecutive years of corporate tax rate data. Country-years may have both base-broadeners and base-narrowers, so the number of country-years with any base change is less than the number of countryyears with base-broadeners plus the number of country-years with base-narrowers.

Table 4: Frequency of country-years with base-broadening and base-narrowing measures

\begin{tabular}{c|ccccc}
\hline \hline Number of & \multicolumn{5}{|c}{ Number of base broadeners } \\
base narrowers & 0 & 1 & 2 & 3 & 4 \\
\hline 0 & 436 & 112 & 27 & 4 & 1 \\
1 & 82 & 24 & 8 & 4 & 0 \\
2 & 10 & 6 & 0 & 0 & 0 \\
3 & 5 & 2 & 0 & 2 & 0 \\
4 & 2 & 0 & 0 & 0 & 0 \\
\hline
\end{tabular}

Sources: Authors' compilation of information from IBFD Annual Reports, 1980-2002, 2004. 
Table 5: Tax Rate and Tax Base Changes, by Country

\begin{tabular}{|c|c|c|c|c|c|c|c|c|}
\hline \multirow[b]{2}{*}{ Country } & \multicolumn{6}{|c|}{ Frequencies } & \multicolumn{2}{|c|}{ Counts } \\
\hline & $\mathrm{dt}>0$ & $\mathrm{dt}<0$ & $\mathrm{dt}=0$ & dBase $>0$ & dBase $<0$ & $\mathrm{dBase}=0$ & $\begin{array}{c}\text { Base } \\
\text { broadeners }\end{array}$ & $\begin{array}{c}\text { Base } \\
\text { narrowers }\end{array}$ \\
\hline Australia & 2 & 4 & 18 & 10 & 10 & 9 & 16 & 15 \\
\hline Austria & 1 & 1 & 22 & 9 & 7 & 11 & 11 & 10 \\
\hline Belgium & 0 & 5 & 19 & 8 & 4 & 13 & 11 & 4 \\
\hline Canada & 0 & 5 & 19 & 7 & 2 & 16 & 9 & 4 \\
\hline Czech Republic & 1 & 7 & 6 & 3 & 5 & 17 & 3 & 6 \\
\hline Denmark & 2 & 6 & 16 & 5 & 2 & 18 & 8 & 2 \\
\hline Finland & 3 & 4 & 17 & 6 & 1 & 18 & 6 & 2 \\
\hline France & 1 & 6 & 17 & 11 & 9 & 8 & 13 & 12 \\
\hline Germany & 2 & 5 & 17 & 8 & 8 & 12 & 14 & 16 \\
\hline Greece & 4 & 4 & 16 & 5 & 2 & 19 & 6 & 2 \\
\hline Hungary & 0 & 5 & 11 & 8 & 7 & 12 & 12 & 8 \\
\hline Iceland & 1 & 5 & 4 & 0 & 0 & 25 & 0 & 0 \\
\hline Ireland & 1 & 9 & 14 & 6 & 5 & 15 & 6 & 5 \\
\hline Italy & 2 & 3 & 19 & 9 & 9 & 12 & 15 & 9 \\
\hline Japan & 2 & 5 & 17 & 11 & 5 & 12 & 16 & 9 \\
\hline Korea & 1 & 4 & 19 & 8 & 6 & 13 & 10 & 7 \\
\hline Luxembourg & 0 & 8 & 16 & 3 & 12 & 12 & 3 & 13 \\
\hline Netherlands & 1 & 6 & 17 & 12 & 8 & 10 & 13 & 11 \\
\hline New Zealand & 2 & 1 & 21 & 5 & 1 & 19 & 5 & 1 \\
\hline Norway & 1 & 0 & 23 & 3 & 4 & 20 & 3 & 4 \\
\hline Poland & 0 & 6 & 8 & 3 & 5 & 18 & 4 & 5 \\
\hline Portugal & 4 & 8 & 12 & 8 & 8 & 12 & 10 & 9 \\
\hline Slovak Rep. & 0 & 5 & 7 & 0 & 4 & 21 & 0 & 5 \\
\hline Spain & 1 & 0 & 23 & 8 & 10 & 9 & 12 & 13 \\
\hline Sweden & 1 & 4 & 19 & 9 & 4 & 13 & 9 & 4 \\
\hline Switzerland & 1 & 2 & 21 & 0 & 0 & 25 & 0 & 0 \\
\hline Turkey & 3 & 2 & 17 & 4 & 2 & 19 & 4 & 2 \\
\hline United Kingdom & 0 & 7 & 17 & 12 & 1 & 12 & 15 & 1 \\
\hline United States & 1 & 2 & 21 & 9 & 4 & 16 & 14 & 6 \\
\hline Total & 38 & 129 & 473 & 190 & 145 & 436 & 248 & 185 \\
\hline
\end{tabular}

Sources: Authors' compilation of information from IBFD Annual Reports, 1980-2002, 2004 and tax rate data as described in Section III. 
Table 6: Replications of key results in Clausing (2007) and Devereux (2006)

\begin{tabular}{|c|c|c|c|c|c|c|}
\hline \multirow[b]{2}{*}{ VARIABLES } & $(1)$ & $(2)$ & $(3)$ & $(4)$ & $(5)$ & (6) \\
\hline & \multicolumn{2}{|c|}{ Dependent variable } & \multicolumn{4}{|c|}{ Corporate tax revenue/GDP } \\
\hline Corp. tax rate & $\begin{array}{c}0.276^{* * *} \\
(0.072)\end{array}$ & $\begin{array}{c}1.285^{*} \\
(0.704)\end{array}$ & $\begin{array}{c}0.908 * * \\
(0.344)\end{array}$ & $\begin{array}{c}0.235^{* * *} \\
(0.075)\end{array}$ & $\begin{array}{c}0.368 \\
(0.700)\end{array}$ & $\begin{array}{c}0.214 \\
(0.685)\end{array}$ \\
\hline Corp. tax rate $(\mathrm{sq})$ & $\begin{array}{c}-0.455^{* * *} \\
(0.131)\end{array}$ & $\begin{array}{c}-2.094^{* *} \\
(0.928)\end{array}$ & $\begin{array}{c}-1.627^{* *} \\
(0.614)\end{array}$ & $\begin{array}{c}-0.401^{* * *} \\
(0.130)\end{array}$ & $\begin{array}{l}-0.786 \\
(1.044)\end{array}$ & $\begin{array}{l}-0.735 \\
(1.010)\end{array}$ \\
\hline Worldwide & $\begin{array}{c}0.243 \\
(0.377)\end{array}$ & & & $\begin{array}{c}0.318 \\
(0.361)\end{array}$ & & \\
\hline GDP growth rate & $\begin{array}{c}0.057 \\
(0.036)\end{array}$ & & & $\begin{array}{c}0.056 \\
(0.036)\end{array}$ & & \\
\hline Unemp. rate & $\begin{array}{c}-0.086^{* *} \\
(0.040)\end{array}$ & & & $\begin{array}{c}-0.089^{* *} \\
(0.039)\end{array}$ & & \\
\hline Log GDP-per-cap. & $\begin{array}{l}0.558^{*} \\
(0.275)\end{array}$ & & & $\begin{array}{c}0.510^{*} \\
(0.265)\end{array}$ & & \\
\hline Individual tax - corporate tax & $\begin{array}{c}0.002 \\
(0.015)\end{array}$ & & & & & \\
\hline International $*$ Tax & $\begin{array}{c}0.025 \\
(0.065)\end{array}$ & & & $\begin{array}{c}0.058 \\
(0.101)\end{array}$ & & \\
\hline International $*$ Tax sq. & $\begin{array}{l}-0.000 \\
(0.001)\end{array}$ & & & $\begin{array}{l}-0.001 \\
(0.002)\end{array}$ & & \\
\hline $\operatorname{Big} * \operatorname{Tax}$ & $\begin{array}{c}-0.090^{* *} \\
(0.041)\end{array}$ & & & $\begin{array}{c}0.276 \\
(0.164)\end{array}$ & & \\
\hline Big * Tax sq. & $\begin{array}{c}0.002^{* *} \\
(0.001)\end{array}$ & & & $\begin{array}{l}-0.003 \\
(0.002)\end{array}$ & & \\
\hline Other corp. tax rates & & $\begin{array}{c}-0.688 \\
(0.582)\end{array}$ & & & $\begin{array}{c}-0.976 \\
(0.748)\end{array}$ & \\
\hline Depreciation $\mathrm{x}$ tax & & $\begin{array}{l}-0.014 \\
(0.009)\end{array}$ & $\begin{array}{c}-0.010^{* *} \\
(0.004)\end{array}$ & & $\begin{array}{l}-0.003 \\
(0.009)\end{array}$ & $\begin{array}{l}-0.001 \\
(0.009)\end{array}$ \\
\hline Depreciation $\mathrm{x}$ tax (sq) & & $\begin{array}{l}0.023^{*} \\
(0.011)\end{array}$ & $\begin{array}{c}0.018 * * \\
(0.007)\end{array}$ & & $\begin{array}{c}0.006 \\
(0.013)\end{array}$ & $\begin{array}{c}0.006 \\
(0.013)\end{array}$ \\
\hline Depreciation $\mathrm{x}$ other tax rates & & $\begin{array}{c}0.004 \\
(0.005)\end{array}$ & & & $\begin{array}{c}0.007 \\
(0.007)\end{array}$ & \\
\hline Personal tax rate & & & $\begin{array}{c}-0.064 \\
(0.125)\end{array}$ & $\begin{array}{c}0.003 \\
(0.015)\end{array}$ & & $\begin{array}{c}-0.085 \\
(0.132)\end{array}$ \\
\hline Depreciation $\mathrm{x}$ pers. tax rate & & & $\begin{array}{c}0.001 \\
(0.002)\end{array}$ & & & $\begin{array}{c}0.001 \\
(0.002)\end{array}$ \\
\hline International & & & & $\begin{array}{c}-0.612 \\
(0.932)\end{array}$ & & \\
\hline Big & & & & $\begin{array}{c}-6.595^{* *} \\
(2.939)\end{array}$ & & \\
\hline Depreciation & & & & & $\begin{array}{c}-0.334 \\
(0.318)\end{array}$ & $\begin{array}{c}-0.179 \\
(0.186)\end{array}$ \\
\hline Constant & $\begin{array}{c}-6.042^{* *} \\
(2.916)\end{array}$ & $\begin{array}{c}19.471 \\
(17.862)\end{array}$ & $\begin{array}{c}0.784 \\
(0.486)\end{array}$ & $\begin{array}{c}-4.905^{*} \\
(2.800)\end{array}$ & $\begin{array}{c}45.357 \\
(31.795)\end{array}$ & $\begin{array}{c}14.622 \\
(14.363)\end{array}$ \\
\hline Implied revenue-max. rate & 30.1 & 27.5 & 29.6 & 29.3 & 27.8 & 29.8 \\
\hline Observations & 665 & 475 & 472 & 665 & 475 & 472 \\
\hline R-squared & 0.368 & 0.266 & 0.260 & 0.379 & 0.275 & 0.263 \\
\hline
\end{tabular}


Table 7: Regressions with country fixed-effects

\begin{tabular}{|c|c|c|c|c|c|c|}
\hline \multirow[b]{2}{*}{ VARIABLES } & $(1)$ & $(2)$ & \multirow{2}{*}{$\begin{array}{c}(3) \\
\text { e: Corporat }\end{array}$} & \multirow{2}{*}{\multicolumn{2}{|c|}{$\begin{array}{cc}(4) & (5) \\
\text { e tax revenue/GDP }\end{array}$}} & \multirow[t]{2}{*}{ (6) } \\
\hline & Depen & dent variab] & & & & \\
\hline Corp. tax rate & $\begin{array}{l}0.121^{*} \\
(0.059)\end{array}$ & $\begin{array}{l}0.773^{*} \\
(0.424)\end{array}$ & $\begin{array}{l}-0.097 \\
(0.176)\end{array}$ & $\begin{array}{c}0.040 \\
(0.042)\end{array}$ & $\begin{array}{c}0.124 \\
(0.490)\end{array}$ & $\begin{array}{l}-0.065 \\
(0.445)\end{array}$ \\
\hline Corp. tax rate (sq) & $\begin{array}{r}-0.120^{*} \\
(0.068)\end{array}$ & $\begin{array}{l}-0.897^{*} \\
(0.473)\end{array}$ & $\begin{array}{l}-0.118 \\
(0.399)\end{array}$ & $\begin{array}{l}-0.070 \\
(0.063)\end{array}$ & $\begin{array}{l}-0.010 \\
(0.625)\end{array}$ & $\begin{array}{l}-0.159 \\
(0.660)\end{array}$ \\
\hline GDP growth rate & $\begin{array}{c}0.044 \\
(0.027)\end{array}$ & & & $\begin{array}{c}0.042 \\
(0.027)\end{array}$ & & \\
\hline Unemp. rate & $\begin{array}{l}-0.045 \\
(0.031)\end{array}$ & & & $\begin{array}{l}-0.036 \\
(0.030)\end{array}$ & & \\
\hline Log GDP-per-cap. & $\begin{array}{c}0.175 \\
(0.539)\end{array}$ & & & $\begin{array}{l}-0.034 \\
(0.602)\end{array}$ & & \\
\hline Individual tax - corporate tax & $\begin{array}{c}0.038 \\
(0.027)\end{array}$ & & & & & \\
\hline International * Tax & $\begin{array}{c}0.016 \\
(0.022)\end{array}$ & & & $\begin{array}{c}0.082^{* *} \\
(0.035)\end{array}$ & & \\
\hline International $*$ Tax sq. & $\begin{array}{l}-0.000 \\
(0.001)\end{array}$ & & & $\begin{array}{c}-0.002^{* *} \\
(0.001)\end{array}$ & & \\
\hline $\operatorname{Big} * \operatorname{Tax}$ & $\begin{array}{l}-0.003 \\
(0.022)\end{array}$ & & & $\begin{array}{l}0.200 \\
(0.135)\end{array}$ & & \\
\hline Big * Tax sq. & $\begin{array}{c}0.001 \\
(0.001)\end{array}$ & & & $\begin{array}{l}-0.002 \\
(0.002)\end{array}$ & & \\
\hline Dividend system $=$ classical & $\begin{array}{c}0.233 \\
(0.247)\end{array}$ & $\begin{array}{l}0.509^{*} \\
(0.283)\end{array}$ & $\begin{array}{c}0.392 \\
(0.310)\end{array}$ & $\begin{array}{c}0.524^{* *} \\
(0.240)\end{array}$ & $\begin{array}{l}0.512^{*} \\
(0.285)\end{array}$ & $\begin{array}{c}0.393 \\
(0.310)\end{array}$ \\
\hline Dividend system=imputation & $\begin{array}{c}0.287 \\
(0.235)\end{array}$ & $\begin{array}{c}0.686^{* *} \\
(0.319)\end{array}$ & $\begin{array}{l}0.707^{*} \\
(0.353)\end{array}$ & $\begin{array}{r}0.641^{* *} \\
(0.270)\end{array}$ & $\begin{array}{c}0.708^{* *} \\
(0.318)\end{array}$ & $\begin{array}{l}0.707^{*} \\
(0.359)\end{array}$ \\
\hline Central bank assets/GDP & $\begin{array}{l}-0.359 \\
(1.877)\end{array}$ & $\begin{array}{c}-12.166^{* *} \\
(4.883)\end{array}$ & $\begin{array}{c}-9.797^{* *} \\
(4.215)\end{array}$ & $\begin{array}{l}-0.369 \\
(1.994)\end{array}$ & $\begin{array}{c}-12.463^{* *} \\
(4.741)\end{array}$ & $\begin{array}{c}-9.800^{* *} \\
(4.230)\end{array}$ \\
\hline Other corp. tax rates & & $\begin{array}{l}-0.637^{*} \\
(0.357)\end{array}$ & & & $\begin{array}{c}-0.806^{* *} \\
(0.369)\end{array}$ & \\
\hline Depreciation $\mathrm{x}$ tax & & $\begin{array}{l}-0.010^{*} \\
(0.005)\end{array}$ & $\begin{array}{c}0.001 \\
(0.002)\end{array}$ & & $\begin{array}{l}-0.002 \\
(0.006)\end{array}$ & $\begin{array}{c}0.001 \\
(0.006)\end{array}$ \\
\hline Depreciation $\mathrm{x}$ tax (sq) & & $\begin{array}{l}0.012^{*} \\
(0.006)\end{array}$ & $\begin{array}{c}0.002 \\
(0.004)\end{array}$ & & $\begin{array}{c}0.000 \\
(0.008)\end{array}$ & $\begin{array}{c}0.002 \\
(0.008)\end{array}$ \\
\hline Depreciation $\mathrm{x}$ other tax rates & & $\begin{array}{c}0.005 \\
(0.003)\end{array}$ & & & $\begin{array}{l}0.007^{*} \\
(0.004)\end{array}$ & \\
\hline Personal tax rate & & & $\begin{array}{c}0.177^{* * *} \\
(0.060)\end{array}$ & $\begin{array}{c}0.048 \\
(0.029)\end{array}$ & & $\begin{array}{c}0.178^{* * *} \\
(0.061)\end{array}$ \\
\hline Depreciation $\mathrm{x}$ pers. tax rate & & & $\begin{array}{c}-0.002^{* * *} \\
(0.001)\end{array}$ & & & $\begin{array}{r}-0.002^{* *} \\
(0.001)\end{array}$ \\
\hline International & & & & $\begin{array}{l}-0.828^{*} \\
(0.433)\end{array}$ & & \\
\hline Big & & & & $\begin{array}{l}-3.437 \\
(2.555)\end{array}$ & & \\
\hline Depreciation & & & & & $\begin{array}{c}-0.232^{*} \\
(0.128)\end{array}$ & $\begin{array}{c}0.009 \\
(0.113)\end{array}$ \\
\hline Constant & $\begin{array}{l}-3.074 \\
(6.201)\end{array}$ & $\begin{array}{c}14.016 \\
(10.667)\end{array}$ & $\begin{array}{c}0.650 \\
(1.908)\end{array}$ & $\begin{array}{l}-1.234 \\
(6.809)\end{array}$ & $\begin{array}{c}31.628^{* *} \\
(12.417)\end{array}$ & $\begin{array}{c}0.003 \\
(8.097)\end{array}$ \\
\hline Implied revenue-max. rate & 34.5 & 75.1 & 36.3 & 28.5 & 76.1 & 36.6 \\
\hline Observations & 627 & 449 & 449 & 537 & 449 & 449 \\
\hline R-squared & 0.400 & $0.35 \overline{p 9}$ & 0.402 & 0.396 & 0.361 & 0.402 \\
\hline
\end{tabular}


Table 8: First-difference regressions with aggregate tax base measures

\begin{tabular}{|c|c|c|c|c|c|}
\hline \multirow{3}{*}{$\begin{array}{l}\text { VARIABLES } \\
\text { Change in corp. tax rate }\end{array}$} & \multirow{2}{*}{$\begin{array}{c}(1) \\
\text { Depende }\end{array}$} & $(2)$ & $(3)$ & $(4)$ & \multirow[t]{2}{*}{$(5)$} \\
\hline & & nt variabl & : Corpora & revenue $/ \mathrm{G}$ & \\
\hline & $\begin{array}{c}-0.004 \\
(0.013)\end{array}$ & $\begin{array}{l}-0.004 \\
(0.013)\end{array}$ & $\begin{array}{c}-0.0004 \\
(0.013)\end{array}$ & $\begin{array}{c}0.001 \\
(0.013)\end{array}$ & $\begin{array}{c}0.005 \\
(0.012)\end{array}$ \\
\hline Change in corp. tax rate (sq) & $\begin{array}{c}0.009 \\
(0.021)\end{array}$ & $\begin{array}{c}0.009 \\
(0.020)\end{array}$ & $\begin{array}{c}-0.0001 \\
(0.019)\end{array}$ & $\begin{array}{c}-0.000004 \\
(0.025)\end{array}$ & $\begin{array}{l}-0.013 \\
(0.026)\end{array}$ \\
\hline Some corp. tax base broadeners & & $\begin{array}{l}-0.004 \\
(0.035)\end{array}$ & $\begin{array}{l}0.069^{*} \\
(0.039)\end{array}$ & $\begin{array}{r}-0.0001 \\
(0.036)\end{array}$ & $\begin{array}{c}0.081^{* *} \\
(0.040)\end{array}$ \\
\hline Some corp. tax base narrowers & & $\begin{array}{c}0.050 \\
(0.041)\end{array}$ & $\begin{array}{c}0.056 \\
(0.046)\end{array}$ & $\begin{array}{c}0.054 \\
(0.043)\end{array}$ & $\begin{array}{c}0.065 \\
(0.050)\end{array}$ \\
\hline Change in personal tax rate & & & $\begin{array}{c}0.010 \\
(0.014)\end{array}$ & & $\begin{array}{c}0.011 \\
(0.015)\end{array}$ \\
\hline Change in other country corp. rates & & & $\begin{array}{l}0.045^{*} \\
(0.025)\end{array}$ & & $\begin{array}{l}0.047^{*} \\
(0.026)\end{array}$ \\
\hline Change in GDP growth & & & $\begin{array}{c}0.001 \\
(0.011)\end{array}$ & & $\begin{array}{c}0.001 \\
(0.011)\end{array}$ \\
\hline Change in unemployment rate & & & $\begin{array}{c}-0.104^{* * *} \\
(0.020)\end{array}$ & & $\begin{array}{c}-0.105^{* * *} \\
(0.020)\end{array}$ \\
\hline Change in central bank assets/GDP & & & $\begin{array}{c}-0.921 \\
(1.191)\end{array}$ & & $\begin{array}{c}-0.960 \\
(1.210)\end{array}$ \\
\hline Change in rate $\mathrm{x}$ broadened & & & & $\begin{array}{c}-0.131 \\
(0.102)\end{array}$ & $\begin{array}{l}-0.146 \\
(0.098)\end{array}$ \\
\hline Change in rate $(\mathrm{sq}) \mathrm{x}$ broadened & & & & $\begin{array}{c}0.198 \\
(0.139)\end{array}$ & $\begin{array}{c}0.233 \\
(0.139)\end{array}$ \\
\hline Change in rate $\mathrm{x}$ narrowers & & & & $\begin{array}{c}0.076 \\
(0.056)\end{array}$ & $\begin{array}{l}0.098^{*} \\
(0.057)\end{array}$ \\
\hline Change in rate $(\mathrm{sq}) \mathrm{x}$ narrowers & & & & $\begin{array}{c}-0.101 \\
(0.074)\end{array}$ & $\begin{array}{c}-0.123^{*} \\
(0.068)\end{array}$ \\
\hline Observations & 614 & 614 & 526 & 614 & 526 \\
\hline R-squared & 0.000 & 0.002 & 0.065 & 0.007 & 0.075 \\
\hline
\end{tabular}


Table 9: First-difference regressions with individual tax base measures

\begin{tabular}{|c|c|c|c|c|c|c|c|}
\hline VARIABLES & $\begin{array}{c}(1) \\
\Delta \text { Corp. } \\
\text { Tax Revenue }\end{array}$ & $\begin{array}{c}(2) \\
\Delta \text { Corp. } \\
\text { Tax Revenue }\end{array}$ & $\begin{array}{l}(3 a) \\
+1\end{array}$ & $\begin{array}{c}(3 \mathrm{~b}) \\
-1\end{array}$ & $\begin{array}{l}(4 a) \\
\text { Level } \\
\text { effect }\end{array}$ & $\begin{array}{c}(4 \mathrm{~b}) \\
\mathrm{x} \Delta \text { tax rate }\end{array}$ & $\begin{array}{c}(4 \mathrm{c}) \\
\text { rate (sq) } \\
\mathrm{x} \Delta \operatorname{tax}\end{array}$ \\
\hline Change in corp. tax rate & $\begin{array}{c}-0.006 \\
(0.014)\end{array}$ & $\begin{array}{l}-0.003 \\
(0.015)\end{array}$ & $\begin{array}{c}-0.003 \\
(0.013)\end{array}$ & & $\begin{array}{c}-0.003 \\
(0.016)\end{array}$ & & \\
\hline Change in corp. tax rate (sq) & $\begin{array}{c}0.010 \\
(0.021)\end{array}$ & $\begin{array}{c}0.002 \\
(0.021)\end{array}$ & $\begin{array}{c}0.003 \\
(0.019)\end{array}$ & & $\begin{array}{c}0.001 \\
(0.023)\end{array}$ & & \\
\hline Other broadening measures & $\begin{array}{l}-0.065 \\
(0.080)\end{array}$ & $\begin{array}{c}0.061 \\
(0.064)\end{array}$ & $\begin{array}{c}0.088 \\
(0.090)\end{array}$ & $\begin{array}{c}0.062 \\
(0.094)\end{array}$ & $\begin{array}{l}-1.001 \\
(0.709)\end{array}$ & $\begin{array}{c}0.070 \\
(0.043)\end{array}$ & $\begin{array}{c}-0.106 \\
(0.063)\end{array}$ \\
\hline Other rate changes & $\begin{array}{c}0.035 \\
(0.051)\end{array}$ & $\begin{array}{c}0.060 \\
(0.056)\end{array}$ & $\begin{array}{c}0.134 \\
(0.089)\end{array}$ & $\begin{array}{c}0.008 \\
(0.077)\end{array}$ & $\begin{array}{l}-0.787 \\
(0.773)\end{array}$ & $\begin{array}{c}0.046 \\
(0.042)\end{array}$ & $\begin{array}{l}-0.059 \\
(0.053)\end{array}$ \\
\hline $\mathrm{CFC}$ & $\begin{array}{c}0.173 \\
(0.122)\end{array}$ & $\begin{array}{c}0.104 \\
(0.119)\end{array}$ & $\begin{array}{c}0.108 \\
(0.120)\end{array}$ & & $\begin{array}{c}2.694 \\
(1.662)\end{array}$ & $\begin{array}{c}-0.146 \\
(0.091)\end{array}$ & $\begin{array}{c}0.196 \\
(0.123)\end{array}$ \\
\hline Thin capitalization & $\begin{array}{c}-0.303^{*} \\
(0.175)\end{array}$ & $\begin{array}{c}-0.205 \\
(0.153)\end{array}$ & $\begin{array}{c}-0.285^{*} \\
(0.161)\end{array}$ & & $\begin{array}{c}2.613 \\
(1.854)\end{array}$ & $\begin{array}{c}-0.128 \\
(0.109)\end{array}$ & $\begin{array}{c}0.135 \\
(0.157)\end{array}$ \\
\hline Loss carry forward & $\begin{array}{l}-0.058 \\
(0.115)\end{array}$ & $\begin{array}{l}-0.045 \\
(0.120)\end{array}$ & $\begin{array}{c}0.265 \\
(0.204)\end{array}$ & $\begin{array}{l}0.200^{*} \\
(0.110)\end{array}$ & $\begin{array}{c}-0.009 \\
(0.692)\end{array}$ & $\begin{array}{l}-0.003 \\
(0.050)\end{array}$ & $\begin{array}{c}0.005 \\
(0.075)\end{array}$ \\
\hline Loss carry back & $\begin{array}{l}-0.021 \\
(0.080)\end{array}$ & $\begin{array}{c}0.028 \\
(0.109)\end{array}$ & $\begin{array}{c}-0.295 \\
(0.226)\end{array}$ & $\begin{array}{c}-0.153 \\
(0.172)\end{array}$ & $\begin{array}{c}-1.664 \\
(1.948)\end{array}$ & $\begin{array}{c}0.109 \\
(0.109)\end{array}$ & $\begin{array}{l}-0.158 \\
(0.144)\end{array}$ \\
\hline Accelerated depreciation & $\begin{array}{c}0.015 \\
(0.065)\end{array}$ & $\begin{array}{c}0.076 \\
(0.074)\end{array}$ & $\begin{array}{c}0.086 \\
(0.122)\end{array}$ & $\begin{array}{l}-0.114 \\
(0.105)\end{array}$ & $\begin{array}{c}-1.028 \\
(1.359)\end{array}$ & $\begin{array}{c}0.057 \\
(0.069)\end{array}$ & $\begin{array}{l}-0.069 \\
(0.084)\end{array}$ \\
\hline Investment credits & $\begin{array}{c}0.021 \\
(0.047)\end{array}$ & $\begin{array}{c}-0.005 \\
(0.066)\end{array}$ & $\begin{array}{c}0.069 \\
(0.081)\end{array}$ & $\begin{array}{c}0.069 \\
(0.105)\end{array}$ & $\begin{array}{c}0.481 \\
(0.559)\end{array}$ & $\begin{array}{l}-0.024 \\
(0.035)\end{array}$ & $\begin{array}{c}0.029 \\
(0.051)\end{array}$ \\
\hline Anti-evasion measures & $\begin{array}{c}-0.033 \\
(0.063)\end{array}$ & $\begin{array}{c}0.008 \\
(0.064)\end{array}$ & $\begin{array}{l}-0.022 \\
(0.064)\end{array}$ & & $\begin{array}{c}0.016 \\
(0.927)\end{array}$ & $\begin{array}{l}-0.001 \\
(0.055)\end{array}$ & $\begin{array}{c}0.004 \\
(0.080)\end{array}$ \\
\hline Taxation of foreign comp. & $\begin{array}{l}-0.025 \\
(0.067)\end{array}$ & $\begin{array}{c}-0.070 \\
(0.083)\end{array}$ & $\begin{array}{c}0.185 \\
(0.147)\end{array}$ & $\begin{array}{c}0.273^{* * *} \\
(0.085)\end{array}$ & $\begin{array}{c}5.821^{* *} \\
(2.561)\end{array}$ & $\begin{array}{c}-0.285^{* *} \\
(0.126)\end{array}$ & $\begin{array}{c}0.327^{* *} \\
(0.153)\end{array}$ \\
\hline Foreign tax credit & $\begin{array}{c}-0.097 \\
(0.117)\end{array}$ & $\begin{array}{l}-0.092 \\
(0.126)\end{array}$ & $\begin{array}{c}0.121 \\
(0.184)\end{array}$ & $\begin{array}{c}0.175 \\
(0.121)\end{array}$ & $\begin{array}{c}-9.802^{* * *} \\
(2.368)\end{array}$ & $\begin{array}{c}0.502^{* * *} \\
(0.130)\end{array}$ & $\begin{array}{c}-0.636^{* * *} \\
(0.171)\end{array}$ \\
\hline R\&D credit & $\begin{array}{c}0.199 * * \\
(0.092)\end{array}$ & $\begin{array}{l}0.195^{* *} \\
(0.079)\end{array}$ & $\begin{array}{c}0.241^{* * *} \\
(0.078)\end{array}$ & $\begin{array}{c}-0.216^{* *} \\
(0.086)\end{array}$ & $\begin{array}{c}3.933^{* *} \\
(1.810)\end{array}$ & $\begin{array}{l}-0.169^{*} \\
(0.085)\end{array}$ & $\begin{array}{l}0.180^{*} \\
(0.100)\end{array}$ \\
\hline Change in personal tax rate & & $\begin{array}{c}0.009 \\
(0.014)\end{array}$ & $\begin{array}{c}0.011 \\
(0.015)\end{array}$ & & $\begin{array}{c}0.010 \\
(0.015)\end{array}$ & & \\
\hline Change in other country corp. rates & & $\begin{array}{c}0.028 \\
(0.024)\end{array}$ & $\begin{array}{c}0.044 \\
(0.026)\end{array}$ & & $\begin{array}{c}0.036 \\
(0.026)\end{array}$ & & \\
\hline Change in GDP growth & & $\begin{array}{c}0.001 \\
(0.011)\end{array}$ & $\begin{array}{l}-0.002 \\
(0.012)\end{array}$ & & $\begin{array}{c}0.005 \\
(0.011)\end{array}$ & & \\
\hline Change in unemployment rate & & $\begin{array}{c}-0.100^{* * *} \\
(0.021)\end{array}$ & $\begin{array}{c}-0.109 * * * \\
(0.021)\end{array}$ & & $\begin{array}{c}-0.098^{* * *} \\
(0.023)\end{array}$ & & \\
\hline Change in central bank assets/GDP & & $\begin{array}{l}-1.690 \\
(1.097)\end{array}$ & $\begin{array}{l}-1.253 \\
(1.067)\end{array}$ & & $\begin{array}{l}-1.624 \\
(1.325)\end{array}$ & & \\
\hline $\begin{array}{l}\text { Observations } \\
\text { R-squared }\end{array}$ & $\begin{array}{c}614 \\
0.018\end{array}$ & $\begin{array}{c}526 \\
0.071\end{array}$ & $\begin{array}{c}526 \\
0.101\end{array}$ & & $\begin{array}{c}526 \\
0.102\end{array}$ & & \\
\hline
\end{tabular}

Notes: Robust standard errors in parentheses. $* * * p_{i} 0.01, * * p_{i} 0.05, * p_{i} 0.1$. 
Table 10: First-difference regression with dynamics

\begin{tabular}{|c|c|c|c|}
\hline VARIABLES & $\begin{array}{c}(1 \mathrm{a}) \\
\Delta \text { Corp. Rev./GDP }\end{array}$ & $\begin{array}{c}(1 \mathrm{~b}) \\
\mathrm{t}-1\end{array}$ & $\begin{array}{l}(1 \mathrm{c}) \\
\mathrm{t}+1\end{array}$ \\
\hline Change in corp. tax rate & $\begin{array}{l}0.0001 \\
(0.005)\end{array}$ & $\begin{array}{c}-0.003 \\
(0.008)\end{array}$ & $\begin{array}{c}0.002 \\
(0.005)\end{array}$ \\
\hline Other broadening measures & $\begin{array}{c}0.085 \\
(0.075)\end{array}$ & $\begin{array}{c}0.048 \\
(0.046)\end{array}$ & $\begin{array}{c}0.021 \\
(0.051)\end{array}$ \\
\hline Other rate changes & $\begin{array}{c}0.077 \\
(0.058)\end{array}$ & $\begin{array}{l}-0.057 \\
(0.039)\end{array}$ & $\begin{array}{l}-0.039 \\
(0.051)\end{array}$ \\
\hline $\mathrm{CFC}$ & $\begin{array}{c}0.161 \\
(0.128)\end{array}$ & $\begin{array}{l}0.290^{*} \\
(0.160)\end{array}$ & $\begin{array}{l}-0.009 \\
(0.180)\end{array}$ \\
\hline Thin capitalization & $\begin{array}{l}-0.344^{*} \\
(0.176)\end{array}$ & $\begin{array}{l}-0.315^{*} \\
(0.160)\end{array}$ & $\begin{array}{l}0.082 \\
(0.146)\end{array}$ \\
\hline Loss carry forward & $\begin{array}{l}-0.004 \\
(0.130)\end{array}$ & $\begin{array}{l}-0.035 \\
(0.087)\end{array}$ & $\begin{array}{c}0.011 \\
(0.072)\end{array}$ \\
\hline Loss carry back & $\begin{array}{l}-0.045 \\
(0.160)\end{array}$ & $\begin{array}{l}-0.094 \\
(0.130)\end{array}$ & $\begin{array}{l}-0.036 \\
(0.109)\end{array}$ \\
\hline Accelerated depreciation & $\begin{array}{c}0.062 \\
(0.070)\end{array}$ & $\begin{array}{c}0.124 \\
(0.107)\end{array}$ & $\begin{array}{c}0.046 \\
(0.080)\end{array}$ \\
\hline Investment credits & $\begin{array}{c}0.026 \\
(0.079)\end{array}$ & $\begin{array}{l}-0.121^{*} \\
(0.071)\end{array}$ & $\begin{array}{c}0.037 \\
(0.092)\end{array}$ \\
\hline Anti-evasion measures & $\begin{array}{l}-0.015 \\
(0.069)\end{array}$ & $\begin{array}{c}0.037 \\
(0.062)\end{array}$ & $\begin{array}{c}0.052 \\
(0.086)\end{array}$ \\
\hline Taxation of foreign comp. & $\begin{array}{l}-0.068 \\
(0.090)\end{array}$ & $\begin{array}{c}0.104 \\
(0.098)\end{array}$ & $\begin{array}{c}-0.191^{* * *} \\
(0.049)\end{array}$ \\
\hline Foreign tax credit & $\begin{array}{l}-0.127 \\
(0.138)\end{array}$ & $\begin{array}{l}-0.126^{*} \\
(0.067)\end{array}$ & $\begin{array}{c}0.003 \\
(0.139)\end{array}$ \\
\hline R\&D credit & $\begin{array}{c}0.183 \\
(0.113)\end{array}$ & $\begin{array}{l}-0.028 \\
(0.073)\end{array}$ & $\begin{array}{l}-0.070 \\
(0.126)\end{array}$ \\
\hline Change in personal tax rate & $\begin{array}{c}0.012 \\
(0.016)\end{array}$ & & \\
\hline Change in other country corp. rates & $\begin{array}{c}0.040 \\
(0.032)\end{array}$ & & \\
\hline Change in GDP growth & $\begin{array}{c}0.001 \\
(0.011)\end{array}$ & & \\
\hline Change in unemployment rate & $\begin{array}{c}-0.096^{* * *} \\
(0.024)\end{array}$ & & \\
\hline Change in central bank assets/GDP & $\begin{array}{l}-1.955 \\
(1.275)\end{array}$ & & \\
\hline Observations & 495 & & \\
\hline R-squared & 0.114 & & \\
\hline
\end{tabular}




\section{A Data Appendix}

In this Data Appendix, we provide details of the methodology employed to translate summaries of tax policy changes into indicator variables for types of changes to the corporate income tax base. These indicator variables are derived from summaries of important tax policies published in the International Bureau of Fiscal Documentation's Annual Report publications. For each of the variables, changes that broaden the corporate tax base are coded as +1 while changes that shrink the tax base are coded as -1 .

Table 11: Description of corporate tax base indicator variables

Research and development tax credit

-1 Research and/or development credit (or deduction) was made available or extended; Additional deduction of research costs was permitted.

+1 Research and/or development credit (or deduction) was reduced.

Credits for foreign taxes paid

-1 Foreign tax credit was introduced or increased; the foreign tax credit became easier to obtain; ability to carry forward or back the foreign tax credit was made available or extended; losses could be used to offset foreign source income.

+1 The scope for the foreign tax credit was reduced or denied; Limitation to the offset of foreign-source losses (Germany 1982).

Tax treatment of foreign companies

-1 Tax exemptions, deductibility of costs, or other investment incentives aimed at attracting foreign investment or multinational headquarter placement; Limited taxation or tax-exempt status of (some) non-resident companies; Liberalization of inward foreign investment; Reduced corporate taxes on companies with a foreign holding; Holdings in foreign corporations granted new exemptions (Germany 1993); Lower tax rates extended to EU companies where previously only applied to resident companies (Greece 2000); Foreign company entry made easier (Korea 1994).

+1 Tax incentives to foreign investors or foreign companies were reduced or withdrawn; Benefits to dual resident companies denied; Certain tax rules extended to non-resident companies; Definition of a resident corporation was expanded; Taxes on income derived from subsidiaries in tax privileged countries was imposed; Limited deduction of expenses of branch offices of non-resident companies; Final withholding on non-resident corporations increased; Deduction for expenses between resident and non-EC companies were disallowed (Italy $1991 / 2)$. 
Policies that target evasion or avoidance by companies

-1 Increased efforts to combat evasion or avoidance, unless specifically directed at the individual level only, including provisions addressing international profit shifting, provisions to curtail the underground economy and a temporary tax amnesty to encourage the repatriation of capital illegally held abroad.

Investments credits or other tax incentives to promote investment

-1 Investment allowance/premium/deduction was introduced, increased or extended; Exclusion of certain investments from taxation; Tax holiday for investment projects or capital investments; incentives to promote investment; Safe harbor leasing rules for investment credits.

+1 Investment premium or deduction was abolished, reduced or restricted; Companies were no longer allowed to allocate profits to a tax-free investment reserve.

\section{Accelerated depreciation or other depreciation allowances}

-1 Increased depreciation rates; Depreciation period shortened; Accelerated writeoff of capital expenditures; Threshold for depreciation was increased; Special depreciation allowances granted; Free depreciation scheme introduced.

+1 Use of accelerated depreciation was reduced or abolished; Depreciation rates were reduced; Depreciation period was extended.

Other tax rates that may affect the corporate tax base

-1 Additional tax on business: Exceptional company profits or extraordinary business income (Hungary 1998; Portugal 1987); Excess accumulated income (Korea 1994); Municipal business tax on capital (Luxembourg 1998); Assets tax (Mexico 1995); Special temporary corporation tax (Japan 1994); Branch profits tax (Australia, 1987); Enterprise tax (Japan 1997). Company formation tax: (Hungary 1998). Capital taxes: Property transfer tax (Austria 1987); Transfer of capital (Spain 1980); Income from the increase in invested capital (Italy 1998). Development land tax: (UK 1985). Specific business types: Shipping (Portugal 1991); Foreign technology licensors (Korea 1988).

+1 Additional tax on corporations: Surtax on corporations or surcharge on corporate income tax (France 1995 1997; Germany 1991; Turkey 1995); Large corporation tax on capital (Canada 1989, 1990); Flat tax on tax-reserves of companies (Greece 1998); Special temporary corporation tax (Japan 1991); Special corporate rate on exempt entities (Spain 1987); Branch profits tax (US 1986). Specific business types: Large banks, investment funds or financial institutions (Austria 1981; Denmark 1989; France 1981; Korea 1982); Life insurance companies (Australia 1988; Germany 1993; Sweden 1986); Oil companies or oil windfall profits tax (France 1980, 1981, 2000; Norway 1980; US 1986); Manufacturing profits tax on computer software and data processing firms (Ireland 1984); Telecommunications (Turkey 1999). Capital taxes: Immovable property (Belgium 1994, Germany 1982; Spain 1991); Movable capital (Portugal 1980, 1983). Surcharge on the employment fund: Luxembourg 1991, 1994. 
Loss carry-forward

-1 Loss-carry forward was extended or expanded; Limits for carry-forward loss amounts were removed.

+1 Ability to carry forward losses was suspended or restricted.

Loss carry-back

-1 Loss carry-back was introduced.

+1 Ability to carry back losses was restricted.

Thin capitalization rules

+1 Thin capitalization rules were introduced or strengthened (widened); Adjustments were made to thin capitalization rules (assumed to be positive); debt-toequity ratio was reduced.

Controlled foreign company legislation

+1 CFC legislation was introduced or redefined.

Other changes to the corporate tax base

-1 Eased tax burden of companies generally (Netherlands, 1983)

New deduction or exemption permitted: Losses from disposal of fixed assets (Czech Republic 1995); Investment abroad (France 1988); Payroll (France 1998); Cost of issuing new shares (Germany 1984); New employees (Ireland 1982); Bonuses to directors (Portugal 1999); Undistributed profits that are wholly reinvested (Greece 1988); Repatriated earnings (Ireland 1988); Income from overseas services if not taxed in the source country (Australia, 1980)

Corporate income tax incentives in the form of a credit (Hungary 2002)

Participation exemption under the corporate income tax was extended (Luxembourg 1988)

Level of income below which a proportion tax reduction is allowed was raised (Finland 1984)

+1 Measures to or emphasis on broadening the tax base, without mention of specific provisions (Hungary 1994; Japan 1998; Mexico 1987; US 1982; Turkey 1981)

Taxable base for lower rate was increased (Korea 1989)

Previous tax incentives restricted or abolished (Poland 1992)

Credits reformulated resulting in a sharp decrease in benefits (Spain 1988)

Certain provisions replaced, expected to keep total tax burden unchanged (Sweden 1989)

Loss of some deduction (Australia 1985; Netherlands 1989); Allowances restricted (Hungary 1991); Expenses were no longer recognized as business-related costs (Hungary 1993); Inventory deduction abolished (Netherlands, 1986)

Extension of employment deduction for small and medium business; reduction of certain tax expenditures (Belgium 1984)

Certain tax exemptions to promote growth of SME (Belgium 1998)

Deductions for corporate entertainment restricted (Japan 1994)

Investment deduction for employee profit sharing schemes eliminated (France 1985)

Maximum amount allowed to be credited to bad debt reserve were reduced (Japan 1982)

Full carry-over of tax benefits from international or contractual agreements (Portugal 1989)

Capital allowances phased out (UK 1984); Corporate AMT extended (US 1986) 